\title{
NUTRIENT STOCKS IN TASMANIAN VEGETATION AND APPROXIMATE LOSSES DUE TO FIRE
}

\author{
by W.D. Jackson
}

(with seven tables and two text-figures)

JaCkSON, W.D., 2000 (31:xii): Nutrient stocks in Tasmanian vegetation and approximate losses due to fire. Pap. Proc. R. Soc. Tasm. 134: 1-18. ISSN 0080-4703. School of Plant Science, University of Tasmania, GPO Box 252-55, Hobart, Tasmania, Australia 7001.

Previously published data on the mass and concentration of major nutrients in Tasmanian vegetation types are presented in common units. The losses of nutrients in intensely hot wild-fires occurring once or twice a century are calculated and used to estimate losses in more frequent but less intense fires. Potential losses from consumed foliage and litter and from erosion and leaching of ash post-fire are estimated. Losses of phosphorus as a percentage of the mass of that element in the above-ground biomass and litter in rainforest or wet and dry eucalypt forest range from $75-85 \%$; losses in scrub, heath and sedgeland range from $35-45 \%$. Losses of $18 \%$ in potassium and $30 \%$ in calcium in sedgeland fires are particularly serious impediments to successional processes in western regions.

Data are provided on the input of nutrients into the precipitation and its attenuation with distance from the coast. In the absence of studies of nutrient balance in Tasmania, the available data from Victoria have been analysed to provide some information which is probably applicable to eastern Tasmania. In addition, the study provides the input-output concentration difference for a number of Tasmanian watersheds and a table showing the outflow concentrations from a selection of catchments displaying a range of geology, precipitation input (P) and evaporation (E). In Tasmania, the large differences in $\mathrm{P} / \mathrm{E}$ ratios between western and eastern catchments has a major nutritional effect. The input of sodium in the Yolande catchment in the west is $1270 \mathrm{ppm}$, but the difference in input-output concentration is only $0.55 \mathrm{ppm}$, whereas the Lisdillon catchment in the east has a sodium in put of $180 \mathrm{ppm}$, but a concentration difference of $20 \mathrm{ppm}$, indicating the effect of high evapotranspiration on the residence time and availability of nutrients. In precipitations of $>2000 \mathrm{~mm}$ in western Tasmania, the large input of nutrients is balanced by equally large outflows from both rainforest and sedgeland. Thus, any additional mineralised nutrients following a fire will probably be lost by erosion, leaching or run-off. The data suggest that hot fire should not be used to regenerate cut-over forests in environments with high $\mathrm{P} / \mathrm{E}$ ratios.

The relatively high predominance of disclimax fire-tolerant vegetation such as sedgeland and scrub in western Tasmania is due to the combination of a long period of Aboriginal burning during the Late Pleistocene and the low occurrence of clay-forming minerals in the geological exposures. In the eastern half, the topographical capping of dolerite has done much to supply an erosional mix of clay-forming minerals, so that the occupation of this region by Aborigines during the Holocene had a lower impact.

Key Words: nutrients, loss, fire, vegetation, Tasmania.

\section{INTRODUCTION}

The long period $(-34000 \mathrm{yrs})$ of occupation of Tasmania by humans has been well documented by Cosgrove (1995: fig. 16). Jackson (1999d) suggested that the period of occupation was likely to have been much longer, because of probable underestimation of age by the $\mathrm{C}^{14}$ dating methodology in Tasmanian conditions (Colhoun 1986). The palaeohistory of the vegetation derived from the Darwin impact crater indicates an anomalous change in the proportions of forest and open vegetation commencing approximately 70000 years ago (Jackson $1999 \mathrm{~d}$ ).

The Aborigines used fire extensively, not merely for cooking and warmth but in communication, as a weapon, in hunting and, most importantly, as a management practice to increase herbivore production. The systematic patchburning of vegetation to create "greenpick" grazing was extensively used. As a consequence of this widespread use, and of the fact that fire was transported from place to place by smouldering firesticks (Ling Roth 1899), many accidental wild-fires were started. Every summer it would be inevitable that fires were already burning when extreme fire-hazard weather occurred, leading to extensive, hot, intense wildfires (Marsden-Smedley 1998). The limited occurrence of lightning-induced fires in Tasmania has been previously noted (Jackson \& Bowman 1982, Ingles 1985, Jackson $1999 \mathrm{~d})$. Thus, the presence of humans using fire intensively would have caused a massive increase in the frequency of wild-fire due to accidental fires in extreme fire-hazard conditions (Jackson 1999d). Jackson advanced the argument, based on the results of an analysis of palaeovegetation history in the core of the Darwin Crater (Colhoun \& van de Geer 1998), that the present large proportion of disclimax vegetation developed over the Last Glacial Cycle as a result of fire associated with the presence of man (Jackson 1999d).

In this recent article (1999d) Jackson revived an earlier thesis (Jackson 1968) that fire, vegetation and soil are closely related via a series of feedback relationships. It was proposed that recurrent fire regimes interrupt the reproductive cycles of plants, causing sudden changes in the distribution of plant communities, if the interval between consecutive fires is either too short or too long the "ecological drift" theory (Jackson 1968, Noble \& Slatyer 1981). Furthermore, recurrent fire encourages vegetation with lower nutrient requirements and greater reliance on vegetative reproduction or dependence on fire for regeneration. Fires cause a direct loss of nutrients by the removal of volatilised elements and particles in the updraft (Harwood \& Jackson 1975, Bowman \& Jackson 1981, Raison et al. 1985a, b, 1990, 1993, Walker et al. 1986, Fisher \& Binkley 2000). Further losses of mineralised nutrients in the ash residue occur through gravitational movement due to wind and water and in solution both in run-off and down the soil profile by leaching (Bowman \& 
Jackson 1981, Bowman et al. 1986, Raison et al. 1993). Such losses relative to gains, from the input in precipitation and from the weathering of the geological parent materials, in time can reduce the availability of nutrients in the soil pool to the extent that vegetation types with a high nutrient demand become restricted. This present paper draws together the available data on nutrient limitation to vegetation in Tasmania and the impacts of fire on it.

\section{FIRE AND NUTRIENT LOSS}

Fire in natural vegetation is a major disruptive factor, changing the above-ground pools of organically complexed nutrients into a volatile or an inorganic mineralised state. Combustion accomplishes in a few minutes the process of nutrient transformation which would normally take five to ten years and, in some cases, much longer by biological decomposition. The loss of nutrient capital due to fire is difficult to estimate. Fire intensity affects nutrient transformations (Raison et al. 1993, Fisher \& Binkley 2000). Hot, intense wild-fires, once they gain sufficient rate of spread, create fire-storm winds and strong convection updrafts which carry gases, burnt vegetation, ash and surface soil to high altitudes to be dispersed downwind, and, in Tasmania, often out to sea (McArthur 1968, Cheney 1981). The fire intensity (energy per metre of fire-front) is in the range $7000-70000 \mathrm{kw} / \mathrm{m}$ and flame heights are $>15 \mathrm{~m}$ (Cheney 1981, Fisher \& Binkley 2000). All the canopy foliage is consumed in such fires along with the understorey and litter. Slow, cool fires consume the litter and foliage up to a few metres leaving most nutrients as residual ash, although about $80 \%$ of the volatile elements $\mathrm{N}$ and $\mathrm{S}$ are lost as gas with significant $40-60 \%$ non-particulate losses of $P$ and K (Raison et al. 1985a, b). Fires which consume the forest duff or peat may burn slowly for long periods, causing massive mineralisation of the nutrient-rich pools of the surface organic soil. In such fires, some of the nutrients stay on the site as ash but are subject to erosion downslope and to leaching down the soil profile (Maclean 1979, Bowman \& Jackson 1981, Bowman et al. 1986).

In most ecosystems, both soil and vegetation are the product of climate, geological influences and disturbances. In the absence of disturbance, the time required to achieve a climatic climax is controlled by geological characteristics such as the weathering rate and the mineral composition of the exposure. Palaeontological evidence from cores of the Darwin Crater in western Tasmania and from the Chatham Rise off the South Island of New Zealand shows that the vegetation has alternated between forest, largely rainforest, and open herbaceous communities with the cycles of glacial and interglacial climates during the Late Pleistocene (Jackson $1999 \mathrm{~d})$. The climax in these ecosystems has been established during each alternation in approximately 2500 years. In these insular temperate climates, the incidence of natural lightning-induced fire is low, and the input of nutrients in the precipitation is high and dependable. In western Tasmania previous to the last glacial cycle, the alternation of forest-herbaceous vegetation occurred on geological exposures of highly siliceous Cambrian and Precambrian sediments, which are very slow weathering and have minimal clay-forming minerals. The present extent of disclimax vegetation in this area appears to be the combination of fire disturbance due to presence of humans during the Last Glacial Cycle and the low inherent fertility of many of the geological exposures of the region. Although most regions of western Tasmania have suffered wild-fire at least once in the last two hundred years (Marsden-Smedley 1998), there are rare forests indicating very long periods of fire-free disturbance. In the Boyd River catchment, small patches of callidendrous rainforest occur on highly infertile Cambrian quartzwacke sediments where the $\mathrm{P}$ content of the parent material is undetectable (Harwood 1972, Jackson 1977). In such instances of low disturbance, the biomass gradually increases its nutrient capital by accumulation of cyclic salt input in the precipitation. Adequate $\mathrm{N}$ is fixed by the large mass of micro-organisms in the epiphytes in the Tasmanian rainforest canopy (Parker 1982).

Fire causes a loss of nutrients from the site due (Raison et al. 1993, Fisher \& Binkley 2000) to

- volatilisation and particle loss in the updraught of the fire,

- wind transport of the ash,

- gravitational movement of the ash and charcoal downslope by run-off water,

- solution in the run-off water and

- leaching of dissolved ions down the soil profile.

Even slow, cool fires which consume little more than the litter layer cause transformation of significant nutrients from complexed biological states to gases or mineral forms that can be solubilised. If the surface organic soil is sufficiently dry at the time of intense fire incidence, it can also be consumed. Such peat or duff fires cause mobilisation of a large proportion of the total nutrient capital of the site, rendering it susceptible to potential leaching and erosion. As Ellis \& Graley (1987) have pointed out, the current vegetation sometimes produces greater changes to soil fertility than the previous fire history. However, the effect of erosion following fire on slopes is a major contribution to soil loss, lower fertility and vegetation change.

\section{VEGETATION AND FIRE}

Short descriptions of the vegetation in Tasmania are available (Jackson 1965, 1981, 1999a) and detailed accounts of the important types are given in the Vegetation of Tasmania (Reid et al. 1999).

In other studies, the general environment (Jackson 1999b, d), the fire environment $(1981,1999 \mathrm{~b}$ : 34-36) and the distribution of vegetation (1999a: figs 1.1, 1.3) have been covered. The areas estimated at 1800 and at present with the average fuel loads and fire-free intervals are shown in table 1 . The following notes on the principal vegetation types supply a brief outline sufficient for an understanding of the influence of recurrent fire on these communities in the past and present.

\section{Alpine and montane vegetation}

Falling embers from hot wild-fires in lowland forests have probably always been a cause of spot-fires in montane regions. However, it is certain that the damage to montane vegetation has increased markedly since European settlement, due principally to the burning practices of graziers operating leaseholds of summer pasturage on the high country. One fire of this source in the summer of 1961-62 burnt nearly 128000 ha (Mitchell 1962). Large proportions of the Athrotaxis forest and coniferous shrubberies were killed (Jackson 1973, Kirkpatrick \& Dickinson 1984b, Kirkpatrick et al. 1995). 
TABLE 1

Areas of vegetation types pre-1800 and at present, fire interval and fuel load

\begin{tabular}{|c|c|c|c|c|c|c|}
\hline Vegetation type & $\begin{array}{c}\% \text { area } \\
\text { pre-European }\end{array}$ & $\begin{array}{l}\% \text { area } \\
\text { present }^{\dagger}\end{array}$ & $\begin{array}{c}\% \text { area } \\
\text { northwest }\end{array}$ & $\begin{array}{c}\% \text { area } \\
\text { southwest }\end{array}$ & $\begin{array}{l}\text { Fire-free } \\
\text { interval yrs }\end{array}$ & $\begin{array}{l}\text { Combustible } \\
\text { fuel t/has }\end{array}$ \\
\hline rainforest & 9.8 & 8.5 & 26.2 & 19.5 & $150-300$ & $25-30$ \\
\hline swampforest & 0.6 & 0.2 & 0.2 & - & $100-200$ & $20-30$ \\
\hline wet sclerophyll & 19.2 & 14.6 & 24.9 & 15.7 & $80-150$ & $180-320$ \\
\hline dry sclerophyll & 43.1 & 23.1 & 2.1 & - & $20-80$ & $20-30$ \\
\hline grassland & 1.3 & 0.8 & 1.1 & - & $10-25$ & $4-8$ \\
\hline heathland & 6.4 & 3.4 & 1 & - & $10-30$ & $10-20$ \\
\hline alpine & 1.7 & 1.7 & 3.2 & 4 & $100-250$ & $10-15$ \\
\hline saltmarsh & 0.06 & 0.05 & - & - & & - \\
\hline wetland & 0.4 & 0.2 & - & - & $40-80$ & $2-4$ \\
\hline sedgeland & 17.4 & 17.2 & 27.4 & 56.2 & $20-40$ & $10-30$ \\
\hline total \% & 100 & 70 & 86.2 & 95.4 & & \\
\hline cleared land \% & - & 30 & 13.8 & 4.6 & & \\
\hline area millions ha & 6.62 & 6.62 & 1.34 & 1.23 & & \\
\hline
\end{tabular}

* Proportionate area of each vegetation type estimated to exist pre European settlement (Kirkpatrick et al. 1995) relative to the whole state of Tasmania.

$\dagger$ Proportionate area (1995) relative to the whole state of Tasmania (Kirkpatrick et al.1995).

₹ Proportionate area of the northwestern quarter (west of Forth River to Mt Manfred, estimate Kirkpatrick \& Dickinson $1984 a$ ).

$\$$ Proportionate area of southwestern quarter protected region (modified after Marsden-Smedley 1998) after allowances for roads and impoundments.

The average interval between consecutive fires (Jackson 1968).

The average quantity of combustible fuel in tonnes per hectare at the time burnt, compiled from a number of sources.

\section{Temperate rainforest}

Fire is rare in rainforest because the closed canopy maintains moisture content well into drought conditions. Low amounts of litter, low flammability and sparse understorey limit invasion of ground fires. The largest threat is from spot-fire embers setting the dense epiphytic moss and lichen load in the canopy alight when humidities are very low.

\section{Mixed forest}

The age of mixed forest varies over a very wide span (Jackson $1999 \mathrm{~d}$; this paper, fig. 1A, table 1). Close to sources of fire from open vegetation, the tree ages are commonly $50-100$ yrs, reflecting the occasional overrun of fire across the forest boundary (fig. 1A). In scattered patches within the sheet of rainforest, ages extend from about 200 to 300 years, the patches of eucalypt overstorey being maintained by chance spot fires often from upwind sources of sedgeland (fig. $1 \mathrm{~B}, \mathrm{C}$ ). The eucalypts in forests approaching 300 years of age are overmature, with moribund crowns, and often have a density of less than five trees per hectare (fig. 1A, $B$ ). The presence of eucalypts with large litter-cones of bark and leaves increases the risk of spot-fires in mixed forest. This elevated mass of sclerophyllous litter is easily ignited by falling embers in times of drought.

\section{Wet sclerophyll forest}

Fires in wet sclerophyll forest are rare but very intense, usually killing all trees. Regeneration is from seed from fireresistant capsules shed soon after crown-fire scorch. Dense stockings result from the large fall of two to four years of viable seed held in the crowns. The consequent thinning over the first 80 years of growth to reduce the stocking from many tens of thousands to about 80 stems per hectare (Gilbert 1959) plus the branch fall from remaining dominant trees contributes to the equilibrium fuel loads of up to $400 \mathrm{t} / \mathrm{ha}$, with litter and duff component up to $160 \mathrm{t} / \mathrm{ha}$ (Frankcombe 1966, Wells \& Hickey 1999). The updraught from the fire-storm of wild-fires in severe fire weather conditions causes a rain of embers downwind, creating spotfires up to more than $50 \mathrm{~km}$ distant (Cheney 1981).

\section{Dry sclerophyll forest}

The fire-free interval is short, ranging from ten or less to about 50 years. There is a continued accumulation of litter fuel in the drier sites in Tasmania due to the slow decay of the sclerophyll litter and limited termite activity. The litter layer contains $50-75 \%$ of the consumable fuel mass, and fuel accumulation continues to $>20 \mathrm{t} /$ ha after 30 years on sites with $<700 \mathrm{~mm}$ precipitation but plateaus around $15 \mathrm{t} / \mathrm{ha}$ on sites with $>700 \mathrm{~mm}$ precipitation (Bresnehan 1998). It seems likely that, in dry Eucalyptus amygdalina forests with a heathy understorey, the steady state of litter accumulation would exceed $30 \mathrm{t} / \mathrm{ha}$. The Eucalyptus dominants of the dry sclerophyll show a marked ability to recover vegetatively from even intense fires by the survival of dormant buds under the dead phloem of the main trunk and larger limbs (Jacobs 1955, Pryor 1976). This epicormic growth sustains carbon fixation till the crown dominance is again asserted. Very dry habitat species recover principally from similar buds in the massive lignotubers (Reid \& Potts 1999).

\section{Grassland/sedgeland}

These communities appear to derive from the burning regimes of the Aborigines during the Holocene. They may be divided into two types:

(a) Open savannah merging into grassy, open dry sclerophyll forest in dry habitats usually $<800 \mathrm{~mm}$ in lowland environments. At the time of European settlement, 
they extended throughout the east and north in the Midlands Graben and in the valleys of the larger streams (Fensham 1989, Jackson 1999d). These sparsely forested areas were quickly usurped by European graziers. Sheepgrazing has removed the previously rich intertussock herb layer and prevented the establishment of forest except at the margins, where advancing pole stands of eucalypts demonstrate the probable nature of the vegetation in the absence of disturbance (Duncan 1990). Where a short interval free of fire is maintained, the shrub storey of dry Eucalypt forest is slowly converted to a grassy sedgy understorey.

(b) Poa billardieri tussock grassland and grassy open $E$. delegatensis forest with corridors of forest on streams. These occur on moderately fertile soils on parent materials of basalt, granite or limestone on plateaus in the north at altitudes of $600-1100 \mathrm{~m}$. These grasslands in the northeast and northwest have been rapidly invaded by forest since European settlement by the succession of LeptospermumEucalyptus-Nothofagus. The eucalypt forest has a short tenure, due to die-back associated with rainforest invasion (Jackson 1981, Ellis 1986).

\section{Heathland}

Due to the intense utilisation of the coastal regions by the Aborigines in the Holocene, heathy communities have been extended inland by fire at the expense of the dry sclerophyll forest. Within the broad region dominated by dry sclerophyll forest there are many small patches of heath on sites where the watertable is high enough to create edaphic limits to trees. These sites are common on duplex soils of Permian and Triassic sediments. It is likely that most heathland was patch-burnt by the Aborigines every ten to 15 years to prevent closure by shrubs and to generate "greenpick" grazing conditions (Kirkpatrick \& Harris 1999).

\section{Sedgeland/heath or blanket moor}

The blanket moor carries sedges and an open shrub element of Epacridaceae, Myrtaceae and Proteaceae (Brown 1999). The moorland will carry fire even in damp conditions and burns intensely in drought. Where the fire-carry or intensity is limited by creeks or polar slopes, a dense wet scrub community of Leptospermum, Agastachys and Bauera develops until it is consumed by a hot fire. In valleys the peat depth may reach over $1 \mathrm{~m}$ but on steep slopes may be no more than a few centimetres. Most fires consume only the aboveground vegetation. From such fires Gymnoschoenus recovers quickly because of the large energy reserves held in the rhizomes. However, after prolonged drought, fires may consume the peat with serious losses of nutrients due to mobilisation and solution (Bowman \& Jackson 1981, Jackson 1999d).

\section{TASMANIAN DATA ON NUTRIENT LOSSES AND INPUTS}

\section{Losses due to Wild-fire and Estimation of Consumable Biomass}

An attempt has been made in table 5 (see later) to collect the available data on potential nutrient loss due to very intense wild-fire in typical examples of vegetation types in Tasmania. This will hopefully provide a nutritional basis for the discussion on the patterns of vegetation discussed by Jackson \& Brown (1999). The basis for the data in table 5 is provided by the estimated consumable masses shown in table 2 , which have been collected from a number of published sources. These sources vary in sampling techniques, methods and analysis; hence, the original sources should be consulted to obtain their relative reliability. However, variability in the accuracy of the source data is small compared with the large potential errors in estimating fire-intensity effects when applying the estimates in table 5 to fires of lower intensity.

Where possible the concentration of elements is expressed in $\mathrm{kg} / \mathrm{ha}$, otherwise in $\mathrm{ppm}$. Elements are denoted by their chemical symbols. Concentrations of the important elements $\mathrm{N}$ and $\mathrm{P}$ are variously assessed in the form of ammonium $\left(\mathrm{NH}^{+}\right)$and available $\mathrm{P}$. Where measured, the available form is used in all tables.

It must be stressed that the losses shown in table 5 are based on the losses incurred in the extremely intense wildfires occurring once or twice a century in Tasmania (Marsden-Smedley 1998). Evidence gained from the inspection of sites which had carried wet sclerophyll forests, dry sclerophyll forests, shrubland and grassland before the 1967 fire in southeastern Tasmania was that complete removal of ash and considerable surface soil was general on all sites, due to the strong updraft.

The losses in these very intense wild-fires are used in table 5 because they allow a complete inventory of losses of nutrients from the fire site. Losses of nutrients in less intense fires are much lower and are highly variable, due to the range of fuel consumed and the range of fire-intensity effects on volatile and particle loss in the smoke, transportation of elements into various mineral states in the ash, consumption of duff, removal of soil in the updraft, heating of the soil, exposure to erosion and leaching (Raison et al. 1993, Fisher \& Binkley 2000). Estimates of losses via atmospheric transfer in burning logging slash in forest regeneration in the Florentine Valley were approximately $15-20 \%$ in $\mathrm{P}, \mathrm{K}, \mathrm{Ca}$ and $\mathrm{Mg}$ (Harwood \& Jackson 1975). Losses of nutrients in smoke during cool fuel-reduction fires are expected to be only $1-5 \%$ of the losses suggested in table 5. However, Raison et al. (1985a, b) have established relationships between the percentage of fuel mass consumed

FIG. 1 (opposite) - (A) Forest structures in environments with precipitation $>1950 \mathrm{~mm}$ per annum as determined by age since the last fire. (B) Vegetation patterns associated with various fire frequencies showing the progressive replacement of rainforest on ridge crest by mixed forest, eucalypt forest, scrub, heath and sedgeland with increasing fire frequency. Pieman River region, Tasmanian west coast; rainfall $2250 \mathrm{~mm} / \mathrm{annum}$. (C) Probability distribution of occurrences of eucalypt stands in rainforest with distance from isolated areas of sedgeland, the assumed sources of fire: (i) measured in a southeasterly direction, i.e. down prevailing wind as the most likely direction of spot-fire production; this direction is also transverse to the dissection pattern and the major geological axis of folding; (ii) measured from the nearest fire source irrespective of direction. The probability distribution illustrates the effect of spot-fires on successive ridges due to embers. Source of data: analysis of 56500 ha of rainforest in the Mt Bertha area; rainfall $2250 \mathrm{~mm}$. 
A

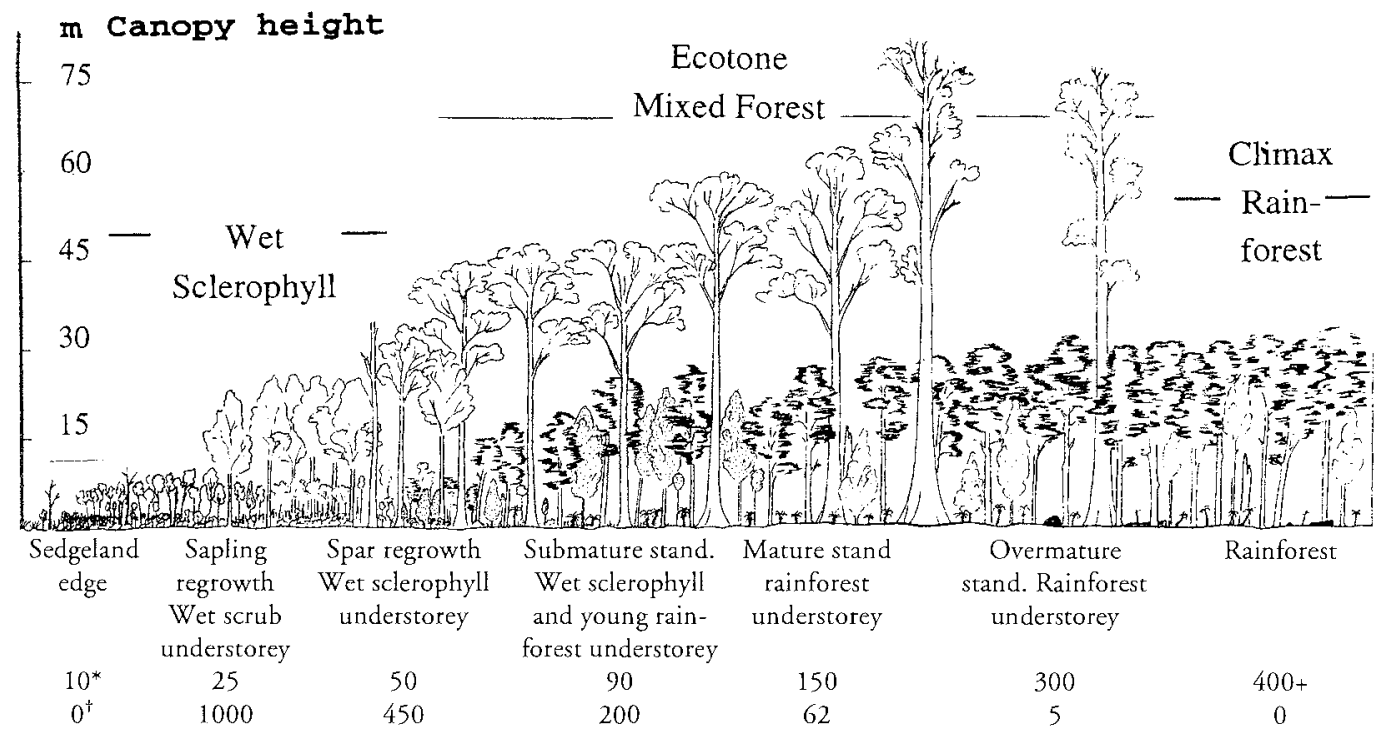

* years since last fire + Eucalypt stems per hectare

\section{B}
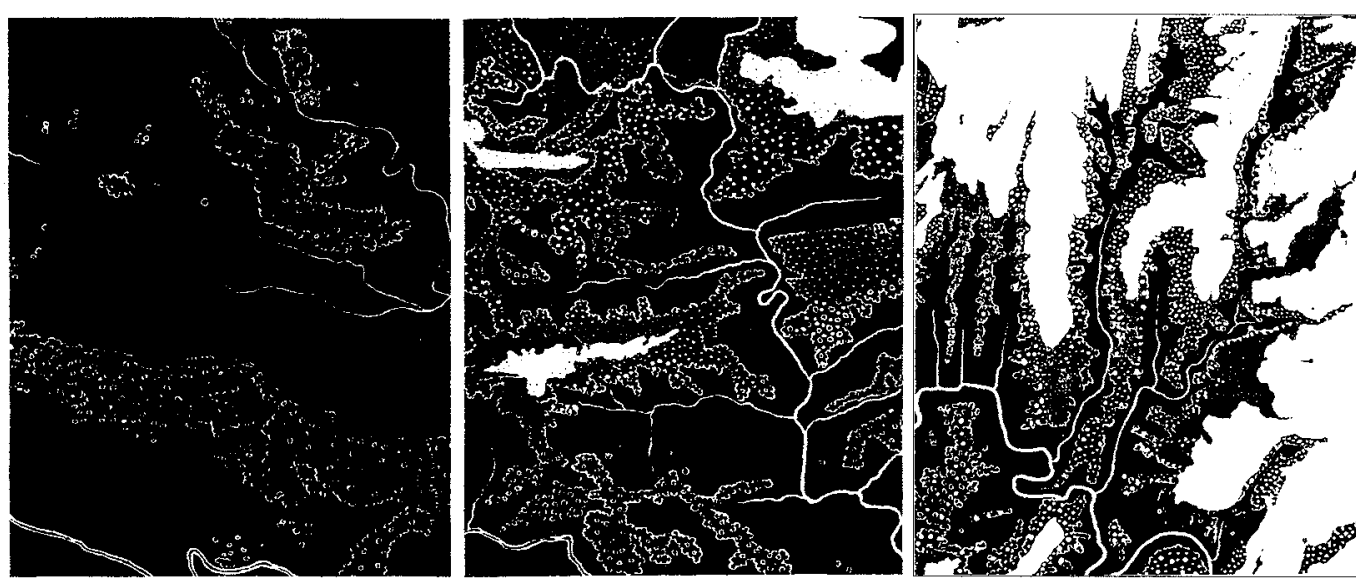

LOH FIRE FREQUENCY

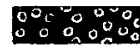

$\because \because \because \because \because$

MEDIUM FIRE FREQUENCY

Rain-

over

mature

spar

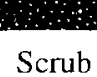

HIGH FIRE FREQUENCY

forest mature

$\Longrightarrow$ Eucalypt Stands

C

$$
P=0.31 \text { AT ZERO }
$$

(i)

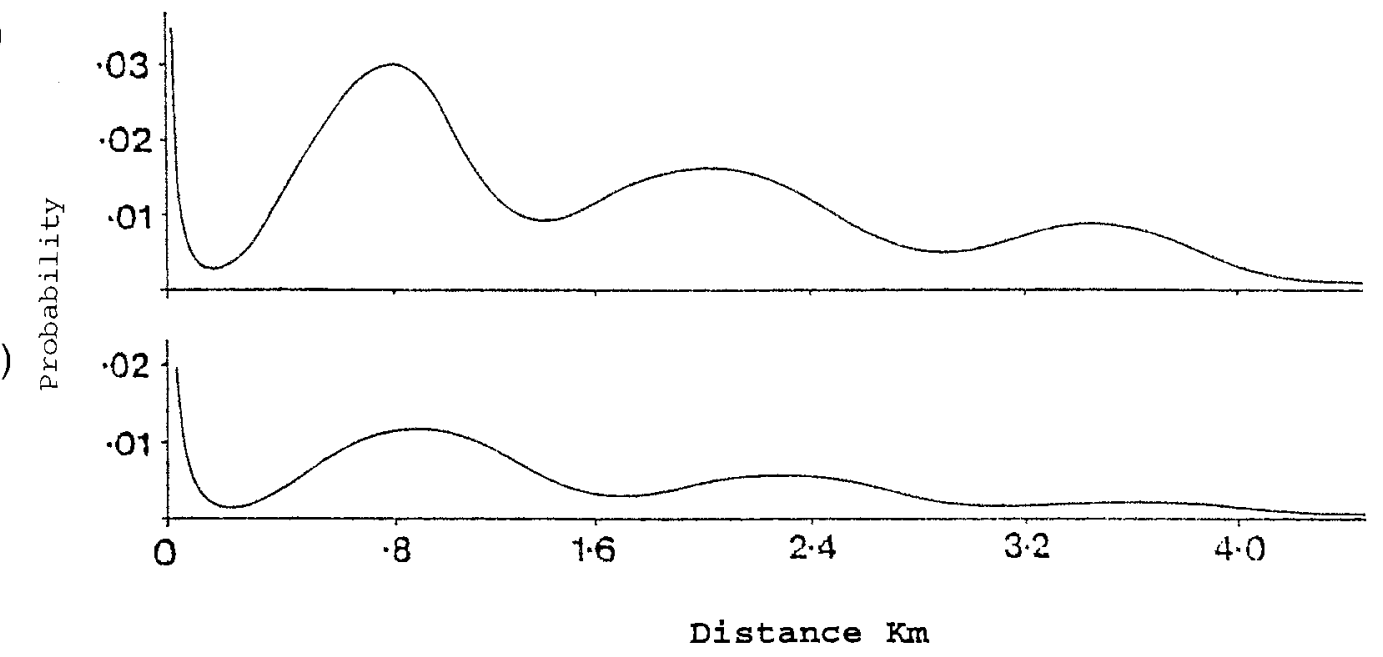


TABLE 2

Sample potential masses of nutrients consumed in intense wild-fires

\begin{tabular}{|c|c|c|c|c|c|c|c|}
\hline \multirow[t]{2}{*}{ vegetation } & \multirow[t]{2}{*}{ component* } & \multirow[t]{2}{*}{ mass (t/ha) } & \multicolumn{5}{|c|}{ elemental concentration $(\mathrm{kg} / \mathrm{ha})$} \\
\hline & & & $\mathrm{N}$ & $\mathrm{P}$ & $\bar{K}$ & $\mathrm{Ca}$ & $\mathrm{Mg}$ \\
\hline callidendrous & foliage & 11.4 & 123.7 & 12.9 & 95.1 & 36.6 & 11.5 \\
\hline rainforest & litter-fall & 4.34 & 27.1 & 2.1 & 11.6 & 18.2 & 2.3 \\
\hline aged $>400$ yrs & o.g. biomass & 493 & 597 & 66 & 603 & 460 & 62 \\
\hline \multicolumn{8}{|l|}{ Saddleback, NE Tas. } \\
\hline $1600 \mathrm{~mm}$ & cons. o.g. mass & 10.57 & 82.3 & 10.05 & 67.7 & 43.2 & 9.36 \\
\hline Jurassic dolerite & litter & 14.3 & 102.9 & 7.85 & 8.58 & 119.4 & 15.3 \\
\hline \multirow[t]{2}{*}{ (Adams \& Attiwill 1988) } & tot. consumable & 24.87 & 185.2 & 17.9 & 76.3 & 162.6 & 24.66 \\
\hline & eq. yrs litter-fall & 5.7 & 6.8 & 8.5 & 6.6 & 8.9 & 10.7 \\
\hline Eucalyptus regnans & foliage & 10.9 & 114.6 & 6.7 & 61.1 & 39.7 & 20.4 \\
\hline wet sclerophyll & litter fall & 5.34 & 32.1 & 1.4 & 9.5 & 25.1 & 5.2 \\
\hline aged $80-100$ yrs & o.g. biomass & 472 & 698 & 39.9 & 419 & 811.9 & 123.2 \\
\hline Retreat, NE Tas. $1000 \mathrm{~mm}$ & cons. o.g. mass & 154.6 & 329.6 & 10.98 & 149.9 & 110.7 & 37.3 \\
\hline Mathinna quartzwacke & litter & 24.5 & 174 & 6.85 & 39.2 & 136.3 & 19.8 \\
\hline \multirow[t]{2}{*}{ (Adams \& Attiwill 1988) } & tot. consumable & 179.1 & 427.2 & 17.83 & 189.1 & 247 & 57.1 \\
\hline & eq. yrs litter-fall & 33.5 & 13.3 & 12.73 & 19.91 & 9.84 & 10.98 \\
\hline E. obliqua & foliage & 6.6 & 80.2 & 4.3 & 25.6 & 27.2 & 15.4 \\
\hline dry sclerophyll & litter fall & 4.31 & 19.51 & 1.01 & 4.2 & 19.7 & 4.8 \\
\hline aged 100 yrs & o.g. biomass & 363 & 430 & 19.2 & 238 & 306 & 62.1 \\
\hline \multicolumn{8}{|l|}{ Emu Ground, NE Tas. } \\
\hline $800 \mathrm{~mm}$ & cons. o.g. mass & 11 & 93.4 & 5.36 & 43.86 & 56.98 & 22.28 \\
\hline Mathinna quartzwacke & litter & 20 & 82.3 & 2.78 & 8.08 & 71.7 & 10.2 \\
\hline \multirow[t]{2}{*}{ (Adams \& Attiwill 1988) } & tot. consumable & 31 & 175.7 & 8.14 & 51.94 & 128.59 & 32.48 \\
\hline & eq. yrs litter-fall & 7.2 & 20.92 & 27.13 & 30.55 & 14.29 & 21.65 \\
\hline E. amygdalina & foliage & 7.6 & 98.9 & 5.2 & 36.3 & 28.8 & 12.4 \\
\hline dry sclerophyll & litter-fall & 1.95 & 8.4 & 0.3 & 1.7 & 9 & 1.5 \\
\hline aged 100 yrs & o.g. biomass & 158 & 281 & 12.1 & 145 & 346 & 46.7 \\
\hline \multicolumn{8}{|l|}{ Turquoise Bluff, NE Tas. } \\
\hline $750 \mathrm{~mm}$ & cons. o.g. mass & 11.2 & 105.3 & 5.7 & 42.6 & 64.8 & 16.4 \\
\hline Mathinna mudstone & litter & 10.3 & 53.5 & 1.33 & 4.47 & 64.5 & 7.18 \\
\hline \multirow{2}{*}{ (Adams \& Attiwill 1988) } & tot. consumable & 21.5 & 158.8 & 7.03 & 47.07 & 129.3 & 23.58 \\
\hline & eq.yrs litter-fall & 11 & 18.9 & 23.4 & 27.7 & 14.4 & 15.7 \\
\hline \multicolumn{8}{|l|}{ E. nitida-Leptospermum } \\
\hline nitidum & foliage & 6.4 & - & 3.18 & 38.9 & 40.5 & 14.7 \\
\hline wet scrub & litter-fall & 2.06 & 12.03 & 0.53 & 3.56 & 9.41 & 1.95 \\
\hline aged 38 yrs & o.g. biomass & 180 & 233 & 13.2 & 140 & 271 & 41 \\
\hline Hastings, $S$ Tas. $1400 \mathrm{~mm}$ & cons, o.g. mass & 57.9 & 123.5 & 3.68 & 55.5 & 41 & 45.5 \\
\hline Cambrian greywacke & litter & 9.17 & 65.3 & 2.57 & 14.7 & 51.1 & 7.6 \\
\hline \multirow[t]{2}{*}{ (Turnbull \& Madden 1983) } & tot. consumable & 67.1 & 188.5 & 6.6 & 70.2 & 92.1 & 53.1 \\
\hline & eq. yrs litter-fall & 10.5 & 15.7 & 33.4 & 48.2 & 37.7 & 27.2 \\
\hline Gymnoschoenus & live foliage & 7 & - & 0.067 & 4.06 & 1.74 & 1.1 \\
\hline sedgeland & dead foliage $/ \mathrm{yr}^{\dagger}$ & 0.01 & - & 0.004 & 0.24 & 1.34 & 0.45 \\
\hline aged $7-30$ yrs & dead fol/30yrs ${ }^{\dagger}$ & 3 & - & 0.12 & 7.29 & 40.2 & 13.5 \\
\hline \multicolumn{8}{|l|}{ Condominium $\mathrm{Ck}$-Orange } \\
\hline R., SW Tas. $2000 \mathrm{~mm}$ & o.g. biomass & 10 & - & 0.187 & 11.35 & 41.5 & 14.6 \\
\hline Precambrian quartzite & cons. o.g. mass & 10 & - & 0.187 & 11.35 & 41.5 & 14.6 \\
\hline \multirow[t]{3}{*}{ (Bowman et al. 1986) } & litter & 0 & - & 0 & 0 & 0 & 0 \\
\hline & tot. consumable & 10 & - & 0.187 & 11.4 & 41.5 & 14.6 \\
\hline & eq. an. fol. death & 3.3 & - & 46.8 & 47.5 & 31 & 32.4 \\
\hline
\end{tabular}

* o.g. = above ground, cons. = consumable, eq. yrs = equivalent number of years of input from litter-fall.

$\dagger$ Dead foliage remains on Gymnoschoenus, the accumulated fuel is a major component of nutrient loss even though the retrievals of $\mathrm{P}$ and $\mathrm{K}$ at senescence are both $94 \%$. (See footnote to table 3 .) 
TABLE 3

Foliar concentrations of major vegetation types in Ppm of oven dry weight

\begin{tabular}{|c|c|c|c|c|c|c|c|}
\hline \multirow[t]{2}{*}{ Vegetation } & \multirow{2}{*}{$\begin{array}{l}\text { Dominant or } \\
\text { important species }\end{array}$} & \multicolumn{4}{|c|}{ Nutrients* } & \multirow[t]{2}{*}{ Site } & \multirow[t]{2}{*}{ Ref. $^{\dagger}$} \\
\hline & & $P$ & K & $\mathrm{Ca}$ & $\mathrm{Mg}$ & & \\
\hline \multirow[t]{2}{*}{ rainforest } & Atherosperma & 1740 & 12980 & 5810 & 1290 & Saddleback, NE Tas & AA \\
\hline & moschatum & $\begin{array}{l}890 \\
{[23]}\end{array}$ & $\begin{array}{c}13100 \\
{[52]}\end{array}$ & $\begin{array}{l}6990 \\
{[58]}\end{array}$ & $\begin{array}{c}725 \\
{[-30]}\end{array}$ & Boyd R., SW Tas & $\mathrm{J}$ \\
\hline \multirow[t]{2}{*}{ " } & Nothofagus & 1540 & 6500 & 2200 & 480 & Saddleback, NE Tas & AA \\
\hline & cunninghamii & $\begin{array}{l}740 \\
{[32]}\end{array}$ & $\begin{array}{l}5450 \\
{[52]}\end{array}$ & $\begin{array}{c}6990 \\
{[56]}\end{array}$ & $\begin{array}{c}720 \\
{[-23]}\end{array}$ & Boyd R., SW Tas & $\mathrm{J}$ \\
\hline gully forest & Olearia argophylla & 1540 & 17800 & 5300 & 1830 & Wallaby Ck, SE Vic & A \\
\hline wet sclerophyll & Eucalyptus regnans & 780 & 5730 & 5730 & 3170 & Wallaby Ck, SE Vic & A \\
\hline$n$ & Pomaderris aspera & 1800 & 11310 & 14234 & 3230 & Wallaby Ck, SE Vic & A \\
\hline " & E. obliqua & 730 & 6660 & 4320 & 2210 & Retreat, NE Tas & AA \\
\hline \multirow{2}{*}{$\begin{array}{c}\text { dry sclerophyll } \\
\text { " }\end{array}$} & E. obliqua & 650 & 3400 & 4140 & 2350 & Emu Ground, NE Tas & AA \\
\hline & E. amygdalina & 700 & 4820 & 3820 & 1640 & Turquoise Bluff, NE Tas & AA \\
\hline grassland & Festuca & 590 & 3280 & 3700 & 1400 & Devonshire Dales, Engl. & Ll \\
\hline wet sclerophyll & E. nitida & $\begin{array}{l}374 \\
{[27]}\end{array}$ & $\begin{array}{c}2880 \\
{[60]}\end{array}$ & $\begin{array}{l}3890 \\
{[-14]}\end{array}$ & $\begin{array}{c}1530 \\
{[5]}\end{array}$ & Boyd R., SW Tas & $\mathrm{J}$ \\
\hline woodland/scrub & & 318 & 3890 & 4050 & 1470 & Condominium Ck, SW T & $\mathrm{M}$ \\
\hline wet scrub & $\begin{array}{l}\text { Leptospermum } \\
\text { nitidum }\end{array}$ & 207 & 3430 & 3550 & 1480 & Condominium Ck, SW T & M \\
\hline dry heath & & 175 & 3300 & 5300 & 2150 & Dark Island Hth, SA & $S$ \\
\hline wet heath & $\begin{array}{l}\text { Melaleuca } \\
\text { squarrosa }\end{array}$ & 122 & 2940 & 8640 & 2020 & Condominium $\mathrm{Ck}$, SW T & M \\
\hline " & $\begin{array}{l}\text { Sprengelia } \\
\text { incarnata }\end{array}$ & 100 & 2450 & 4320 & 670 & Condominium Ck, SW T & M \\
\hline sedgeland & $\begin{array}{l}\text { Lepidosperma } \\
\text { filiforme }\end{array}$ & $\begin{array}{l}113 \\
{[93]}\end{array}$ & $\begin{array}{l}4090 \\
{[93]}\end{array}$ & $\begin{array}{l}540 \\
{[18]}\end{array}$ & $\begin{array}{l}950 \\
{[18]}\end{array}$ & Orange River, SW Tas & M \\
\hline & $\begin{array}{l}\text { Gymnoschoenus } \\
\text { sphaerocephalus }\end{array}$ & $\begin{array}{c}67 \\
{[94]}\end{array}$ & $\begin{array}{l}4060 \\
{[94]}\end{array}$ & $\begin{array}{l}1100 \\
{[23]}\end{array}$ & $\begin{array}{l}1740 \\
{[59]}\end{array}$ & Orange River, SW Tas & M \\
\hline " & $\begin{array}{l}\text { Leptocarpus } \\
\text { tenax }\end{array}$ & 10 & 3300 & 900 & 410 & Orange River, SW Tas & M \\
\hline
\end{tabular}

* Figures in square brackets are the withdrawal percentage of the nutrient upon leaf senescence before leaf-fall; negative figures indicate excretion during senescence.

$\dagger$ References: AA - Adams, M.A. \& Attiwill, P.M. (1988); A - Ashton, D.H. (1975); J - Jackson, W.D. (1977); Ll - Lloyd, P.S. (1971); M - Mclean, A.R. (1979); S - Specht, R.L. (1969).

and the percentage loss of elements to the atmosphere. This demonstrates that up to $40 \%$ of the $\mathrm{P}$ content of combusted fuel can be lost in some low-intensity fires. Erosion of the ash remaining after lower intensity fires is potentially a far greater cause of nutrient loss than either atmospheric or leaching losses (Raison et al. 1985a, 1993). Both erosion and leaching are likely to be important causes of nutrient loss following fire in the dissected high rainfall regions of western Tasmania. The application of the losses estimated in table 5 to fires other than very intense wildfires occurring once or twice a century in Tasmanian vegetation can only be made with due adjustment for the lower fire intensity.

\section{Biomass}

The nutrient status of important Tasmanian plant communities is indicated in table 3 by the foliar concentration of elements in community dominants in approximate order of $\mathrm{P}$ concentration. The distribution of these communities (Kirkpatrick \& Dickinson 1984a, Jackson 1999a) demonstrates the limitations imposed by nutrient availability due to both the prevalence of highly infertile siliceous sediments (Seymour \& Calver 1995) and the fire regimes associated with each vegetation type over a long period of human occupation (table 1).

Except where production is limited by water availability, biomass can reflect lack of disturbance due to the accumulation of nutrient capital in the vegetation and organic soil from the input of cyclic salt. The above-ground biomass in forests is also a function of age, due to wood accumulation. However, while there is a good relationship between foliage mass and the basal area of sapwood, the basal area of accumulated heartwood contributes little to the nutrient mass. This is particularly so in eucalypts, where there is a large transfer of nutrients from the heartwood as it matures (Attiwill 1980). In Tasmania, the total above-ground biomass is often a response to the time since fire and the water availability at the site. In dry sclerophyll forest, fire in the litter and understorey occurs at intervals usually of less than 50 years, but the trees are not killed by even intense fires. In wet sclerophyll and mixed forest, the long fire-free interval and the open canopy of the eucalypts allow the development of large quantities of fuel in the understorey and litter. The consumption of this by fire 
kills most trees. Consequently, the consumable biomass of rainforest and other older mixed forest is lower than that of wet sclerophyll forest.

\section{Nutrient Pools and Fluxes}

The nutrient content of the litter layer and the surface layers of organic soil are probably more important reservoirs of nutrient capital in Tasmanian environments that in most mainland Australian habitats. This proposal is based on the lower decomposition rates of litter, the preponderances of shallow soil, lack of clay-forming minerals and the slow weathering rates and infertility of geological exposures in many Tasmanian habitats. Most feeding roots of vegetation including those of large forest trees exploit mainly the upper few centimetres of the soil profile especially in the infertile soils of western Tasmania. Nutrients in the soil are highly conserved as organic complexes in the micro-organisms. The supply of labile nutrients to the plants via the root system is largely dependent on the flux of nutrients in the litter-fall. The number of years litter-fall equivalent to the loss of nutrients by intense wild-fire is shown in table 5 as a representative measure of nutrient loss.

The pool of micro-organisms in the surface layers of the soil forms an important buffer against losses of nutrients by leaching of the ashes following a fire. The micro-organisms are able to grow rapidly by utilising the flux of nutrient ions dissolved from the ash thus immobilising otherwise labile nutrients. The role of soil micro-organisms in providing immobilisation after a fire is particularly important in forest soils (Vitousek \& Matson 1984, Polglase et al. 1986). For this reason, the consequences of duff and peat fires are particularly detrimental to the regeneration of the vegetation. This is demonstrated by the replacement of rainforest by sedgeland species such as Gahnia, Lepidosperma and Gymnoschoenus following duff fires in poor soils (Hill \& Read 1984, Barker 1991).

\section{Litter Accession and Decomposition}

The standing crop of litter is more variable than the litterfall would indicate, due to the range in decomposition rates. Turnbull \& Madden (1983) analysed the litter balance in southern Tasmanian wet forests near Hastings, where precipitation is $-1400 \mathrm{~mm} / \mathrm{yr}$. These results for litter-fall and standing crop are shown in table 4 and are similar to those of Adams \& Attiwill (1988) for similar communities at Retreat and Saddleback shown in table 2. Turnbull \& Madden (1983) developed a relationship between litter-fall and basal area $\left(\mathrm{r}^{2}=0.92\right)$, where the litter accession in $\mathrm{kg} / \mathrm{ha}$ was $35.7 \mathrm{x}$ (basal area $\mathrm{m} / \mathrm{ha}$ ). This relationship has been used in table 2 to estimate missing data.

Decomposition constants $(\mathrm{k})$ for dry sclerophyll forests in Tasmania are much lower than for wet forests. Although the accession rates are reduced, due to water limitation to production, the much slower decay of litter, due in part to the low activity of termites in Tasmania, more than compensates. Under the high average values of radiation inputs in eastern Tasmania $\left(272-314 \mathrm{~K}\right.$ joules $/ \mathrm{cm}^{2} / \mathrm{yr}$ [Nunez 1978], effectively doubled on steep northerly facing slopes [Holland \& Steyn 1975]), the productivity is predominantly influenced by water availability rather than temperature. Dry sclerophyll in Tasmania is so regularly disturbed by fire that it is difficult to estimate what the steady state of litter might be. In a study of litter accession following fuelreduction fires on sites in southeastern Tasmania, Bresneham (1998) found the $\mathrm{k}$ value for sites with precipitation $>700 \mathrm{~mm} / \mathrm{yr}$ was 0.135 whereas the $\mathrm{k}$ for sites with precipitation $<600 \mathrm{~mm} / \mathrm{yr}$ was 0.0005 , giving an unrealistically high steady state of litter. Accession curves developed by Raison et al. (1983) for dry sclerophyll in the Blue Mountains of NSW suggest that steady states of litter (Xss table 4) in dry sclerophyll in dry regions of Tasmania are about $25-30 \mathrm{t} / \mathrm{ha}$. Such accumulations on dry sites are rare because of fire. It should be pointed out that the E. amygdalina dry sclerophyll on the Turquoise Bluff site (table 5) was burnt two years before the assessment by Adams \& Attiwill (1988) with a fire sufficiently hot to produce a strong crop of epicormic foliage.

\section{Nutrient Loss Relative to Total Pools}

Losses considered relative to the total pools are shown in table 5 where the input in the rainfall is shown in the first row, the consumable mass from table 2 in the second and the exchangeable mass in the upper $5 \mathrm{~cm}$ of the soil pool in the third row. The percentage loss in the above ground pools of foliage and litter relative to the total pools is shown in the last row for each vegetation type. The total pools in the soil are of course much greater than the available pools and the impact of losses in the long term may be in part addressed by the slow conversion of elements from their unavailable pools. However, the losses in intense wild-fire should be assessed against the exchangeable pools as these will determine availability during the regeneration phases. In less intense fires where ash remains, fire mobilises nutrients especially $\mathrm{N}$ and $\mathrm{P}$, stimulating growth of the regeneration. The pool in the top $5 \mathrm{~cm}$ of soil has been used rather than deeper profiles because it has a far greater influence over the early phases of regeneration. Nutrient concentrations in the top $5 \mathrm{~cm}$ are about 4-7 fold greater than those in the next $15 \mathrm{~cm}$ of the soil profile. It has been demonstrated that draw-down on the supply of nutrients in the soil pool decreases after canopy closure, due to the flux of available cations resulting from competitive thinning of the vegetation. Litter-fall produces the majority of supply for $\mathrm{Ca}$ and $\mathrm{Mg}$ and also $\mathrm{N}$, while through-fall supplies most of the $\mathrm{K} . \mathrm{P}$ is predominantly cycled internally in the foliage and as the forest matures from the heartwood (Baker \& Attiwill 1985, Attiwill et al. 1996).

\section{Post-fire Erosion and Leaching Losses}

Residual ash left by cooler fires is subject to erosion and leaching, moving the nutrient content downslope. This movement is considerable in Tasmania, due to the steep slopes of the topography. The first rains after a fire move considerable quantities of ash downslope in the surface run off. Further nutrients are removed in solution. However, quantitative data are difficult to obtain. It is probable that the flotation of charcoal fines over long periods accounts for significant nutrient loss adsorbed from the ash. The evidence of long-term gravitational movement of nutrients is abundant in Western Tasmania, where sedgeland heaths and scrub replace forests on ridge tops where spot fires are more frequent (fig. 1B, C).

The leaching of nutrients from residual ash is limited on 
TABLE 4

Litter decomposition in southern forests*

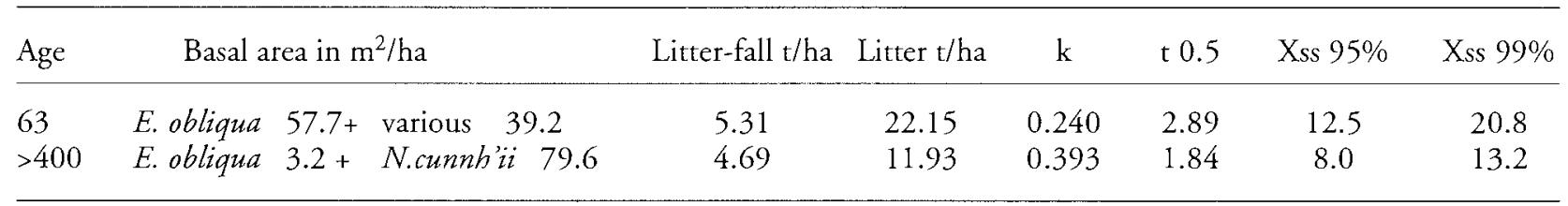

If the decomposition constant $\mathrm{k}$ is defined as $\mathrm{k}=\mathrm{L} / \mathrm{X}$, where $\mathrm{L}$ is the litter fall ( $\mathrm{t} / \mathrm{ha}$ ) and where $\mathrm{X}$ is the litter mass (t/ha), $\mathrm{dx} / \mathrm{dt}=\mathrm{L}-\mathrm{kX}$ then $\mathrm{Xt}$ the litter mass at time $\mathrm{t}(\mathrm{yrs})=\mathrm{L} / \mathrm{k}\left(1-\mathrm{e}^{-\mathrm{kt}}\right)-\mathrm{X} 0\left(\mathrm{e}^{-\mathrm{kt}}\right)$. When $\mathrm{X} 0$ the initial litter mass $=0$, Xt the litter mass at time $t(y r s)=X s s\left(1-e^{-k r}\right)$ where Xss is the steady state (yrs) and t0.5 the half life $=0.693 / \mathrm{k}, \mathrm{t} 95 \%$ ss $=3 / \mathrm{k}$, t $99 \%$ ss $=5 / \mathrm{k}$ (Olsen 1963).

* Turnbull \& Madden 1983.

TABLE 5

Nutrient input and potential loss due to intense wild-fire percentage total pools including the top $5 \mathrm{~cm}$ of soil

\begin{tabular}{|c|c|c|c|c|c|c|c|}
\hline \multirow[t]{2}{*}{ Vegetation type } & \multirow{2}{*}{$\begin{array}{c}\text { Available } \\
\text { nutrient source }\end{array}$} & \multicolumn{6}{|c|}{ Elemental concentration $\mathrm{kg} / \mathrm{ha}$ and $\%$ consumable } \\
\hline & & $\mathrm{N}$ & $\mathrm{P}$ & $\mathrm{Na}$ & $\mathrm{K}$ & $\mathrm{Ca}$ & $\mathrm{Mg}$ \\
\hline rainforest & ann. precip'n input & 8.16 & 0.16 & 12.77 & 10.7 & 12.47 & 2.75 \\
\hline Saddleback & consumable & 185.2 & 17.9 & & 76.3 & 162.6 & 24.7 \\
\hline $1662 \mathrm{~mm}^{*}, 500 \mathrm{yrs}^{\dagger}$ & soil pool & 57.3 & 5.7 & 109.8 & 586.5 & 668 & 136 \\
\hline (Adams \& Attiwill 1988) & cons/tot pool $\%$ & 76 & 76 & & 11.5 & 19.6 & 15.4 \\
\hline wet sclerophyll & ann. precip'n input & 5.28 & 0.13 & 19.25 & 6.92 & 16.78 & 3.33 \\
\hline Retreat & consumable & 427.2 & 17.83 & & 189.1 & 247 & 57.1 \\
\hline $945 \mathrm{~mm}, 120 \mathrm{yrs}$ & soil pool & 445 & 2.5 & 278.23 & 410.6 & 1243 & 533.9 \\
\hline (Adams \& Attiwill 1988) & cons/tot pool $\%$ & 49 & 88 & & 31.5 & 16.6 & 9.7 \\
\hline dry sclerophyll & ann. precip'n input & 3.92 & 0.1 & 22.41 & 4.49 & 13.25 & 3.19 \\
\hline Emu Ground & consumable & 175.7 & 8.14 & & 51.9 & 128.6 & 32.5 \\
\hline $785 \mathrm{~mm}, 40 \mathrm{yrs}$ & soil pool & 145 & 2.2 & 242.7 & 559.1 & 315 & 213.8 \\
\hline (Adams \& Attiwill 1988) & cons/tot pool $\%$ & 55 & 79 & & 8.5 & 29 & 13.2 \\
\hline dry sclerophyll & ann. precip'n input & 3.66 & 0.1 & 20.8 & 3.03 & 13.46 & 3.13 \\
\hline Turquoise Bluff & consumable & 158.8 & 7.03 & & 47.1 & 129.3 & 23.6 \\
\hline $773 \mathrm{~mm}, 15 y \mathrm{rs}$ & soil pool & 180 & 1.3 & 222.1 & 459.4 & 488 & 285 \\
\hline (Adams \& Attiwill 1988) & cons/tot pool $\%$ & 47 & 84 & & 9.3 & 20.9 & 7.6 \\
\hline wet sclerophyll/scrub & ann. precip'n input & -4.2 & -0.15 & -35 & -1.4 & -1.7 & -4.2 \\
\hline Hastings & consumable & -189 & -7 & -26 & -70 & -92 & -53 \\
\hline $1400 \mathrm{~mm}, 30 y r s$ & soil pool & & -1.7 & -180 & -210 & -290 & -315 \\
\hline (Turnbull \& Madden 1983) & cons/tot pool $\%$ & & -80 & -13 & -25 & -24 & -14 \\
\hline wet scrub & ann. precip'n input & & -0.3 & -59 & -10 & -16 & -12 \\
\hline Olga River & consumable & & 1.56 & 16.08 & 31.36 & 18.04 & 66.04 \\
\hline $2500 \mathrm{~mm}, 25 \mathrm{yrs}$ & soil pool & & 2.1 & 160 & 262 & 276 & 574 \\
\hline (Maclean 1979) & cons/tot pool $\%$ & & 43 & 9.1 & 10.7 & 6.5 & 10.3 \\
\hline wet heath & ann. precip'n input & & -0.14 & -45 & -8 & -13 & -10 \\
\hline Condominium $\mathrm{Ck}$ & consumable & & 1.03 & 9.27 & 25 & 47.5 & 8.1 \\
\hline $2000 \mathrm{~mm}, 25 \mathrm{yrs}$ & soil pool & & 1.32 & 105 & 199 & 306 & 226 \\
\hline (Maclean 1979) & cons/tot pool $\%$ & & 44 & 8.1 & 11.2 & 13.4 & 3.5 \\
\hline sedgeland & ann. precip'n input & & -0.3 & -59 & -10 & -16 & -12 \\
\hline Olga River & consumable & & 0.187 & - & 11.4 & 41.5 & 14.6 \\
\hline $2500 \mathrm{~mm}, 25 y \mathrm{rs}$ & soil pool & & 1.19 & - & 53 & 101 & 117 \\
\hline (Maclean 1979) & cons/tot pool $\%$ & & 14 & - & 17.7 & 29 & 11.1 \\
\hline
\end{tabular}

* Annual rainfall ${ }^{\dagger}$ Age of forest. 
forest sites, due to the uptake of nutrients by the regeneration, the high cation-exchange capacity of the surface organic soil and the ability of the extensive microbial pool to expand and immobilise the mineralised nutrients (Vitousek \& Matson 1974, Polglase et al. 1986, Adams \& Attiwill 1988, Attiwill et al. 1996).

The flux of anions, especially bicarbonate, in the leaching water increases the loss of cations initially (Khanna $\&$ Raison 1986). However, in most forest soils, uptake by regenerating vegetation and immobilisation by the microbial pool usually prevent extended leaching, although this is very site-dependent. The analysis of soil water following fire suggests a return to close to prefire levels of nutrients after 18 months (Adams \& Attiwill 1988). Where the surface organic-rich layers are burnt and are subject to severe leaching, the presence of significant clay in the soil profile probably limits extensive leaching losses. Large quantities of nutrients may be captured on the clay. Deep sandy soils without clay horizons are certainly strongly leached after fire. The muck peat soil formed by Gymnoschoenus sedgeland in Tasmania is acid $(\mathrm{pH}-4)$ and anaerobic. It has exceptionally low nutrient content, due to the high withdrawal of nutrients at leaf senescence and the retention of dead foliage by the plant (table 3). As a consequence the loss of potassium in a fire is considerably greater than the content of the soil pool (table 5). Should the peat dry sufficiently to burn, serious erosion and leaching occurs (Maclean 1979, Bowman \& Jackson 1981, Bowman et al. 1986).

\section{Geological Influences}

There are very large differences in the soil-vegetation pools of nutrients on the different geological exposures in Tasmania. However, the more fertile igneous exposures are limited in distribution (Seymour \& Calver 1995).

The input from weathering of geological substrates can only be estimated. An estimate has been made by Attiwill \& Leeper (1987) for weathering inputs for granite soils of high productivity in Victoria. The estimate is possibly applicable to some igneous exposures in eastern Tasmania. However, the lower subsoil temperatures in Tasmania are likely to cause slower weathering rates. Fast-weathering igneous rocks like basalt yield deep clay-loams or kraznozem soils which, in Tasmania, have been largely utilised for agriculture. The much slower weathering exposures of dolerire provide shallow clay-rich loams. These clay-rich soils resist nutrient depletion by erosion and leaching in typical recurrent fire regimes.

The weathering inputs on Permian and Triassic and Devonian sediments are about an order of magnitude lower than those of the igneous rocks, while those of the preCarboniferous sediments of western Tasmania are about two orders of magnitude lower. These highly siliceous, slow-weathering sediments are deficient in clay-forming minerals. The soils on these sediments are shallow, with acid organic surface horizons over leached sandy A1 horizons; they are susceptible to erosion and leaching following fire in the vegetation. Further, the organic soils are likely to be consumed in peat and duff fires, causing serious nutrient loss by erosion. Soil permeability and slope are major factors affecting erosion potential. Erosion is a key driver of soil and vegetation change.

The present maps of geological exposure (Seymour \& Calver 1995) do not account for all of the soil-vegetation responses, because erosion has removed the thin cover of igneous rocks which was once more widely distributed in the west. The clay-forming minerals from these past covers are now incorporated in many soils. Additionally, large volumes of dolerite are perched at elevations $>1000 \mathrm{~m}$ on mountain tops and on the Central Plateau on the western margin of the post-Carboniferous cover. During the Pleistocene, extensive ice-sheets and glaciers have deposited glacial till from the dolerite over wide areas of the preCarboniferous pavement to the west (Colhoun 1985, Kiernan 1989, 1990, Kiernan \& Hannan 1991, Fitzsimons \& Colhoun 1991, Jackson 1999c). The remains of these rocks have been widely distributed by the erosional forces and contribute clay-forming minerals to the soil, increasing its cation-exchange capacity. These relatively small additions of clay minerals do much to prorect the soils on the otherwise highly quartzose sediments in the west from loss of nutrients from leaching after fire. In the eastern half, intensive frost action during periglacial conditions in the Pleistocene has distributed dolerite debris downslope from the capping sills on most of the topography. As a result, clay minerals are incorporated in many soils on sedimentary exposures. The influence of weathering and solution of the geological substrate and concentration due to low precipitation/ evaporation $(\mathrm{P} / \mathrm{E})$ ratios are evident from input-output differences in the streamwaters from the catchments shown in table 6 and the ourflow concentration in table 7 .

\section{Input of Nutrients in the Precipitation (Cyclic Salt)}

There are few data on the nutrient content of rainwater in Tasmania. Adams \& Attiwill's (1988) data from northern Tasmania are the sole available source of information on inputs in precipitation from which attenuation of the elemental concentrations with distance from the coast can be derived. The set of data from the Cape Grim weather station (Ayers \& Ivey 1988) provided an indication of the high maritime influence in the west. Data for eight years showed mean precipitation $794 \mathrm{~mm}$, wind direction $63 \%$ westerly, wind velocity $6-17 \mathrm{~m} / \mathrm{sec} 80 \%$ of time, mean velocity $11-12 \mathrm{~m} / \mathrm{sec}$, mean input of elements in $\mathrm{kg} / \mathrm{ha}$ : $\mathrm{Na}$ 267, $\mathrm{K} \mathrm{11.8,} \mathrm{Ca} \mathrm{15.6,} \mathrm{Mg} \mathrm{30.0.} \mathrm{In} \mathrm{view} \mathrm{of} \mathrm{the} \mathrm{strength} \mathrm{of}$ the westerly airstream and the generally rougher seas in the west, it could be expected that the inputs of aerosols would be higher and the transport of nutrients inland would be higher in the west than in the east. It is expected, therefore, that the data of Adams \& Attiwill (1988) are unlikely to be applicable to western environments. To provide some estimates of the attenuation of nutrient concentration with distance from the western coast, data on the concentration of nutrients in very small natural catchments, such as lakes and tarns surveyed by Buckney \& Tyler (1973), have been utilised to create approximate precipitation inputs. The catchments used are rock basins at high altitudes on hard dolerite or quartzite. The areas drained are all less than a few square kilometres and carry heathy vegetation and shallow peaty soils. The waters have totally dissolved solids ranging from $20-40 \mathrm{ppm}$. These dara are summarised in figure $2 \mathrm{~B}$ for eastern environments using Adams and Atriwill's (1988) data and in figure $2 \mathrm{~A}$ for western environments using Buckney \& Tyler's (1973) data as an approximation. Exponential curves have been fitted to both data sets with respective correlation coefficients. The data collected over 
TABLE 6

Nutrient balance (NB kg/ha/yr) and difference in concentration (CD ppm) both input-output

\begin{tabular}{|c|c|c|c|c|c|c|c|c|c|c|c|c|c|}
\hline \multirow[t]{2}{*}{ Catchment* } & \multirow{2}{*}{$\begin{array}{c}\text { Prec. } \\
\mathrm{mm}\end{array}$} & \multirow{2}{*}{$\begin{array}{c}\text { Evap. } \\
\%\end{array}$} & \multirow{2}{*}{$\begin{array}{c}\text { Dist. } \\
\text { km }\end{array}$} & \multirow{2}{*}{\multicolumn{2}{|c|}{$\begin{array}{l}\mathrm{C}^{*} \mathrm{Yr}_{\mathrm{r}}^{*} \\
\text { no. no. }\end{array}$}} & \multicolumn{2}{|c|}{$\mathrm{Na}$} & \multicolumn{2}{|c|}{ K } & \multicolumn{2}{|c|}{$\mathrm{Ca}$} & \multicolumn{2}{|c|}{$\mathrm{Mg}$} \\
\hline & & & & & & NB & $\mathrm{CD}$ & NB & $\mathrm{CD}$ & $\mathrm{NB}$ & $\mathrm{CD}$ & NB & $\mathrm{CD}$ \\
\hline \multicolumn{14}{|l|}{ Victorian data } \\
\hline Cropper Ck, Myrtlefor & 1200 & 94 & 180 & 1 & 1 & +1.56 & -1.37 & +1.44 & -0.23 & +3.02 & -0.01 & +0.40 & -0.77 \\
\hline loam/shale E. radiata & 1200 & 90 & & 2 & 1 & +1.29 & -1.33 & +1.47 & & +2.82 & & & -0.88 \\
\hline (Flinn et al. 1979 & 1200 & 85 & & 3 & 1 & & -1.79 & +1.27 & & +2.16 & & & -1.51 \\
\hline Stew: & 94 & 83 & 115 & 1 & 1 & +13.2 & -1.17 & +7.30 & -0.18 & +1.60 & -0.11 & -0.10 & -0.08 \\
\hline le $E . o b l$ & 1360 & 73 & & 1 & 2 & 80 & -5.86 & -0.10 & -0 & +0.80 & & -3.50 & -1.00 \\
\hline (Guthrie et al. 1978) & 1432 & 73 & & 1 & 3 & & -5.74 & -1.00 & & +0.80 & & -3.10 & -1.03 \\
\hline Marc & 1554 & 66 & 100 & 1 & 1 & -7.68 & -3.06 & -2.03 & -0.93 & -6.65 & -1.78 & -2.09 & -0.68 \\
\hline kraznozem/gran & 1514 & 47 & & 1 & 2 & -6.91 & -2.02 & -4.28 & -0.57 & -3.42 & -0.76 & -2.68 & -0.48 \\
\hline \multirow[t]{2}{*}{ (Feller 1981) } & 1495 & 51 & & 2 & 1 & -22.44 & -4.09 & -5.19 & -1.04 & -12.69 & -2.60 & -4.70 & -0.77 \\
\hline & 1462 & 43 & & 2 & 2 & -18.26 & -2.74 & -6.63 & -0.67 & -6.16 & -0.88 & -5.91 & -0.76 \\
\hline Tasmanian data ${ }^{\dagger}$ & & & & & & input & $\mathrm{CD}$ & input & $\mathrm{CD}$ & inp & $\mathrm{CD}$ & input & $\mathrm{CD}$ \\
\hline & & & & & & & ppm & $\mathrm{kg} / \mathrm{ha}$ & ppm & $\mathrm{kg} / \mathrm{ha}$ & ppm & $\mathrm{kg} / \mathrm{ha}$ & ppm \\
\hline Fore & 1200 & 87 & 20 & & & .0 & -0.80 & 5.0 & 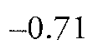 & 4.4 & -0.69 & 3. & -0.19 \\
\hline Lisdillon Rvl. Jd E.glob. & 650 & 130 & 8 & & & 17.9 & -20.2 & 2.3 & -0.51 & 7.8 & -12.84 & 2.6 & -0.98 \\
\hline George R. D. granite $\mathrm{ff} / \mathrm{ws}$ & 950 & 86 & 26 & & & 13.3 & -0.59 & 5.4 & -0.85 & 11.4 & -1.21 & 1.9 & -0.21 \\
\hline Picton R. Pls.E.obl.ws/ & 1800 & 41 & 36 & & & 72.9 & -1.60 & 11.2 & & 14.4 & & 9.0 & -0.94 \\
\hline L St Clair Jd/Pms E.del./rf & 1700 & 40 & 70 & & & 32.3 & -1.12 & 10.0 & -0.43 & 13.6 & +0.02 & 5.1 & +0.16 \\
\hline Yolande R. Cvolc if & 3500 & 21 & 26 & & & 127.5 & -0.55 & 26.3 & -0.19 & 28.0 & -0.12 & 17.5 & -0.34 \\
\hline L. Pedder. Pcqrtz till sedgel & 2700 & 28 & 40 & & & 64.8 & -0.41 & 16.7 & +0.11 & 23.0 & +0.08 & 13.2 & -0.46 \\
\hline
\end{tabular}

${ }^{*} \mathrm{C}=$ catchment, $\mathrm{yr}=$ year, dist. $=$ distance from coast.

${ }^{\dagger}$ Pms = Permian mudstone, $\mathrm{Pl} s=$ Permian limestone, $\mathrm{Jd}=$ Jurassic dolerite, Dss = Devonian siltstone, Cvolc $=$ Cambrian volcanics, Pcqrtz $=$ Precambrian quartzite, $\mathrm{rf}=$ rainforest, ws $=$ wet sclerophyll.

A

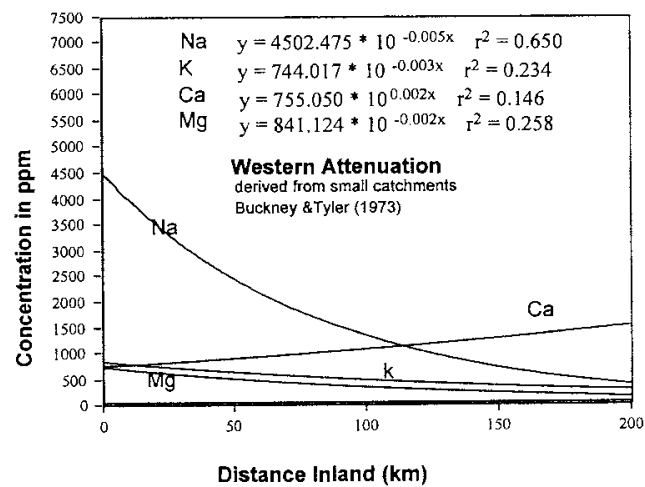

B

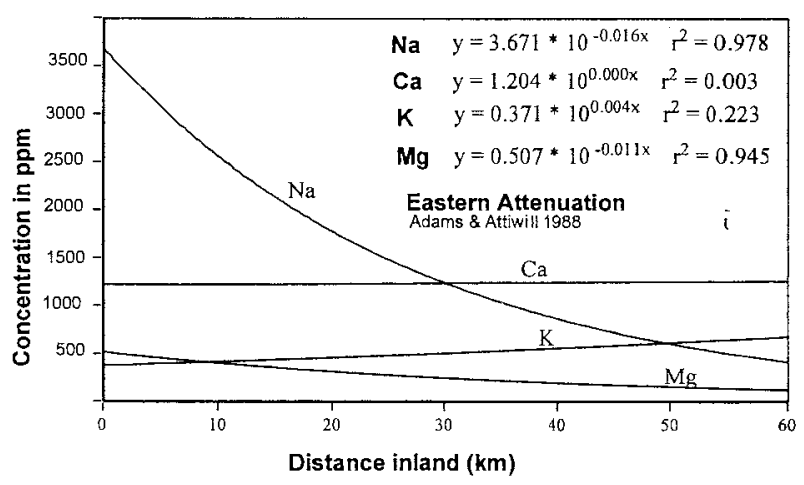

FIG. 2 - Attenuation of nutrients in the precipitation with distance inland. (A) in western Tasmania; (B) in eastern Tasmania. 
TABLE 7

Outflow concentrations of nutrients for sample geological exposures in parts per million*

\begin{tabular}{|c|c|c|c|c|c|c|c|c|c|c|c|}
\hline \multirow{2}{*}{$\begin{array}{l}\text { Princ. geological } \\
\text { exposure }\end{array}$} & \multirow[t]{2}{*}{ catchment } & \multirow[t]{2}{*}{ Vegetn $^{\dagger}$} & \multirow[t]{2}{*}{ Coordinates ${ }^{*}$} & \multirow{2}{*}{$\begin{array}{l}\text { Precip } \\
\mathrm{mm}\end{array}$} & \multirow{2}{*}{$\begin{array}{l}\text { Evapn } \\
\mathrm{mm}\end{array}$} & \multirow{2}{*}{$\mathrm{p} / \mathrm{t}$} & \multicolumn{5}{|c|}{ Elemental concn ppm } \\
\hline & & & & & & & $\mathrm{TDS}^{\S}$ & $\mathrm{Na}$ & $\mathrm{K}$ & $\mathrm{Ca}$ & $\mathrm{Mg}$ \\
\hline \multicolumn{12}{|l|}{ Igneous rocks } \\
\hline Tertiary. basalt & Fossey R.. & $\mathrm{ws} / \mathrm{rf}$ & 8015845102 & 2050 & 750 & 2.7 & 34 & 3.3 & 0.9 & 1.1 & 1.2 \\
\hline Tertiary. basalt & Hatfield R. & ws $/ \mathrm{rf}$ & 8014883018 & 2100 & 750 & 2.8 & 33 & 2.8 & 0.4 & 1.4 & 1.3 \\
\hline Jurassic dolerite & Derwent R. & $\mathrm{ws} / \mathrm{rf}$ & 8113391200 & 1900 & 750 & 2.5 & 25 & 2.2 & 0.7 & 0.4 & 0.3 \\
\hline Jurassic dolerite & Great Lake & $\mathrm{gf} / \mathrm{mont}$ & 8214785605 & 1050 & 1000 & 1.05 & 20 & 1.3 & 0.3 & 1.3 & 0.7 \\
\hline Jurassic dolerite & Lake Leake & E. del gf & 8413659491 & 870 & 1000 & 0.87 & 42 & 3.7 & 1.5 & 2.2 & 1.4 \\
\hline Jurassic dolerite & Lisdillon Rvl. & E. glb $\mathrm{ds}$ & 8413819180 & 725 & 1200 & 0.6 & 174 & 23.9 & 2 & 15 & 9.9 \\
\hline Camb.acid volcanics & Que R. & $\mathrm{rf}^{\circ}$ & 8015902963 & 2200 & 750 & 2.9 & 36 & 3.1 & 0.8 & 2.6 & 0.7 \\
\hline Camb.acid volcanics & Macintosh R. & ws/if & 8015853802 & 2200 & 750 & 2.9 & 37 & 2.2 & 0.7 & 0.6 & 0.3 \\
\hline Camb.acid volcanics & Yolande R. & $\mathrm{rf}$ & 8013769470 & 2600 & 750 & 3.4 & 28 & 2.8 & 0.6 & 0.9 & 0.9 \\
\hline Devonian granodiorite & South Esk R. & E. del.f & 8415741092 & 1200 & 1000 & 1.2 & 32 & 3.4 & 0.4 & 1.6 & 1.3 \\
\hline Devonian granodiorite & St Patricks R. & E. del.f & 8315347283 & 1250 & 1100 & 1.1 & 38 & 3.3 & 0.6 & 1.8 & 1 \\
\hline Devonian adamellite & Groom R. & rf & 8515848348 & 1200 & 1100 & 1.1 & 51 & 5.9 & 0.9 & 1.1 & 1 \\
\hline Cambrian serpentine & Sawback Ck & ws $/ \mathrm{rf}$ & 8112457655 & 1300 & 800 & 1.6 & 42 & 3.1 & 0.6 & 1.9 & 3.9 \\
\hline \multicolumn{12}{|l|}{ Calcareous sediments } \\
\hline Perm. peb.mudstone & Blackfish Ck & ws & 8015882587 & 1100 & 1150 & 1.0 & 81 & 8.9 & 2.5 & 3.2 & 3.1 \\
\hline Permian limestone & Picton R. & $\mathrm{ws} / \mathrm{rf}$ & 8211762270 & 1300 & 900 & 1.4 & 92 & 3.9 & 0.5 & 4.3 & 1.6 \\
\hline Perm. mudst/limest & Sandfly Ck & $\mathrm{d} / \mathrm{ws}$ & 8312142392 & 700 & 1200 & 0.6 & 87 & 3.5 & 0.5 & 31 & 15.2 \\
\hline Ordovician limestone & L. Florentine R. & If & 8112527679 & 1200 & 900 & 1.3 & 152 & 3.1 & 0.5 & 35.2 & 19.1 \\
\hline Precamb. dolomite & Weld R. & $\mathrm{rf}$ & 8112545597 & 1300 & 900 & 1.4 & 211 & 4.3 & 11.8 & 40 & 25 \\
\hline \multicolumn{12}{|l|}{ Siliceous sediments } \\
\hline Dev. quartzwacke & Forester R. & ds & 8415523557 & 785 & 1100 & 0.7 & 42 & 3.4 & 1.0 & 1.0 & 0.9 \\
\hline Camb.greywacke & Whyte R. & $\mathrm{rf}$ & 7915657080 & 2100 & 750 & 2.8 & 57 & 4.3 & 0.3 & 2.2 & 2.7 \\
\hline $\mathrm{PC}$ orth $/ \mathrm{m}$ quartzite & Louisa R. & $\operatorname{sgl}$ & 8111522844 & 1600 & 800 & 2.0 & 72 & 6.6 & 1.4 & 1.5 & 1.8 \\
\hline Dev.quartzite/sst & King R. & $\mathrm{sc} / \mathrm{rf}$ & 8013890400 & 2500 & 750 & 3.3 & 30 & 2.2 & 0.5 & 1.8 & 0.8 \\
\hline PC. metaquartzite & Murchison R. & $\mathrm{sgl} / \mathrm{rf}$ & 8014854754 & 2150 & 750 & 2.9 & 33 & 1.8 & 0.5 & 0.9 & 0.4 \\
\hline PC. metaquartzite & Ck L. Pedder & sgl & 8112320427 & 2600 & 600 & 4.3 & 38 & 2.9 & 0.3 & 0.5 & 0.5 \\
\hline
\end{tabular}

* Reference: Buckney \& Tyler (1973)

$\dagger \mathrm{ws}=$ wet sclerophyll, $\mathrm{ds}=\mathrm{d}$ ry sclerophyll, $\mathrm{rf}=$ rain forest, $\mathrm{gf}=$ grassy forest, mont $=$ montane heath, $\mathrm{sgl}=$ sedgeland, $\mathrm{sc}=$ wet $\mathrm{scrub}$, E. del $=$ Eucalyptus delegatensis, E. glb = Eucalyptus globulus.

* Co-ordinates - the first four digits form the number of the relevant Tasmap 1:100 000 map sheet; this is followed by three digit eastings and northings.

$\S T D S=$ total dissolved solids

two years by Adams \& Attiwill show excellent fits to the data for $\mathrm{Na}$ and $\mathrm{Mg}$ and very poor fits for $\mathrm{K}$ and $\mathrm{Ca}$, with both showing no apparent attenuation. The approximate data for the western environments have reasonable fits by the exponential curves considering their source. Again, the fit for $\mathrm{Ca}$ is poor and the suggested attenuation is positive. The fit for $\mathrm{K}$ is reasonable compared with that in the east. The prediction curves shown in figure $2 \mathrm{~A}, \mathrm{~B}$ should provide some guide as to inputs in precipitation. The ordinate at any distance in ppm $x$ precipitation in $\mathrm{mm} \times 10^{-2}=$ input in $\mathrm{kg}$ / $\mathrm{ha} / \mathrm{yr}$. As expected, there is a considerable difference in the predicted attenuation rates between the western and the eastern environments. The data for Cape Grim and Port Davey would indicate a very rapid attenuation in the first $10 \mathrm{~km}$ from the western coast, so that zero distance on the western attenuation curves represents the input at about $10 \mathrm{~km}$ inland. On the basis of the prevailing source of the wind-borne precipitation, environments south of the Derwent River have been treated as westerly, while environments north of the Derwent and east of the Central Plateau are treated as easterly.

\section{Nutrient Balance and Difference between Input and Output Concentration}

It might be assumed that the relatively large inputs of nutrients in the rainfall are available to the plant communities or can be accumulated in the soil. However, a study of the balance between inputs and outputs, discussed below, shows that accumulation is far more likely in the eastern environments with low $\mathrm{P} / \mathrm{E}$ ratios, and that the western environments with high $\mathrm{P} / \mathrm{E}$ ratios lose nutrients as fast as they enter, so that accumulation is minimal. The impact of fire in mineralising nutrient capital in the vegetation and litter is, therefore, likely to be very much greater in western environments than in eastern ones, due to the high losses through erosion and leaching of ash residue (fig. 2).

No complete nutrient cycling studies determining the nutrient balance (input-output) for a watershed have been conducted in Tasmania. Such studies involve the measurement of input and output volumes as well as input and output masses of elements. There are three studies of catchments in Victoria which supply data probably relevant to catchments in eastern Tasmania (Guthrie et al. 1978, 
Flinn et al. 1979, Feller 1981). These have been summarised in tables by Attiwill \& Leeper (1987: 137-139) and by Attiwill et al. (1996: table 3). In general, these studies show that the order of loss is $\mathrm{Na}>\mathrm{K}>\mathrm{Mg}>\mathrm{Ca}$, with some catchments showing small accumulation of $\mathrm{Ca}$. Comparisons of catchments and years indicate that the nutrient balance is still responsive to the $\mathrm{P} / \mathrm{E}$ ratio, even though it removes the direct effect of evapotranspiration in increasing the concentration of outputs, so that losses of elements tend to increase as the $\mathrm{P} / \mathrm{E}$ ratio rises. As a result, it would seem that the Victorian data on nutrient balance are unlikely to be applicable to the western and southern regions of Tasmania, where $\mathrm{P} / \mathrm{E}$ ratios are high and the vegetation and soil are wet much of the time, due to the trend to uniform rain in all seasons (Jackson 1999b) and to high reliability (Scott 1956).

Data on the difference between input-output in elemental concentration are available for a few catchments in Tasmania from the work on water chemistry by Buckney \& Tyler (1973). These data are limited to comparisons of concentrations in extremely small headwater catchments with downstream concentrations and to single sampling in time. As such, they must be regarded as only an approximate guide to the relative size of the input and output concentrations for the catchments. Since no volume measurements are available for river flows, the data can only be expressed in concentrations (ppm). Table 6 shows the data for the above Victorian catchments for nutrient balance and the difference between input and output concentration for a selection of Tasmanian catchments. The combined data allow a better interpretation of the very different environments across Tasmania. It appears from the collective data for Victoria in table 6 that nutrient accumulation generally increases in drier years, and that losses are greater in wet years so that the nutrient balance does not entirely account for all the evapotranspiration.

The apparent increase in accumulation in the drier sites and years demonstrated by the Victorian data for nutrient balance seems to indicate the conversion of elements into poorly soluble pools in proportion to the long residencetime in the catchments. The opposite tendency for increasing losses in wetter years and catchments probably reflects the flushing of accumulated nutrient in the wetter conditions. The increasing losses in wet years or catchments does not extend to wet environments in Tasmania. The data for difference between input-output concentrations clearly show that, in the very wet environments, the difference in concentration between input-output decreases to zero for elements like $\mathrm{K}$ and $\mathrm{Ca}$ while $\mathrm{Na}$ and $\mathrm{Mg}$ have very low differences of $<0.5 \mathrm{ppm}$.

The parallels between the data on nutrient balance and the difference in input-output concentrations allow some limited application of the Victorian data to Tasmania. It is possible to obtain a rough guide to the effects of $\mathrm{P} / \mathrm{E}$ ratio, marine influence, geological substrate and vegetation. The small positive difference in $\mathrm{K}$ and $\mathrm{Ca}$ at Lake Pedder for instance reflects the high demand for these elements by the Gymnoschoenus and the heath community respectively. The table of concentration differences in inflow-outflow provides useful information on the nutrient environment. For instance, the high $\mathrm{P} / \mathrm{E}$ ratio in the west provides an input to the Yolande catchment of $127 \mathrm{~kg} / \mathrm{ha} / \mathrm{yr}$ of $\mathrm{Na}$ with a balance of only $0.55 \mathrm{ppm}$, whereas the low $\mathrm{P} / \mathrm{E}$ ratio in the east provides an input of $18 \mathrm{~kg} / \mathrm{ha} / \mathrm{yr}$ of $\mathrm{Na}$ for Lisdillon catchment, with a difference between input- output of $20 \mathrm{ppm}$, indicating the effect of high evapotranspiration concentrating the run-off. In contrast, in the western environments the vegetation is awash with water and nutrients which it cannot retain. This means that large erosion and leaching losses must occur following mineralisation of the above-ground vegetation by fire in these wet environments. The very approximate estimates derived from data by Buckney \& Tyler (1973), shown in table 7 , indicate the likely information on nutrient availability in Tasmanian watersheds, due to differing precipitation/evaporation ratios and the degree of weathering and solution of geological substrates which could be obtained from the collection and analysis of rainwater and catchment outflows.

In summary, it appears that the input of nutrients to the soil and vegetation in Tasmania derived from precipitation as cyclic salt and aerosols probably exceeds the input to most watersheds from the weathering of the geological substrate, the possible exceptions being those of basaltic exposures. The climate in Tasmania has been dominated by the marine influence and westerly airstream in all past climates of the Pleistocene, and the low average subsoil temperatures would limit chemical weathering rates. It could be expected, therefore, that the input from weathering in Tasmania is likely to be less and the input from precipitation would be greater than corresponding inputs elsewhere in southeastern Australia.

\section{Peat and Duff Fires}

Peat and duff fires are reasonably common in the cooler wetter climates of Tasmania during periods of extended drought. Peat fires in 1961/62 burnt nearly 128000 ha of the Central Plateau (Mitchell 1962). As a consequence of this fire, approximately one-third of the surface has lost $5-10 \mathrm{~cm}$ of top soil over the subsequent 20 years through sheet erosion (Jackson 1973, Kirkpatrick \& Dickinson 1984b). Duff fires in rainforests in the Frenchmans Cap and Mt McCall regions and in the Denison Range have caused serious erosion in the last twenty years. On this evidence, the damage incurred by duff and peat fires must be significant over the period of a millennium. Elements such as $\mathrm{N}$ and $\mathrm{P}$ are predominantly cycled in the foliage pool. The upper $10 \mathrm{~cm}$ of most organic soils contain $80-90 \%$ of the content of the total pools (Adams \& Attiwill 1988). The consumption of this upper soil zone, therefore, must have a serious impact on future fertility of the site, especially if followed by erosion. The reduced potential of the soil to capture and retain nutrients from the precipitation input is an important factor in limiting the long-term rebuilding of the productivity of the site. Unfortunately, there is little quantitative evidence of leaching loss following peat or duff fires. The only evidence is for losses in a peat fire in the sedgeland/heath at Condominium Creek in the Southwest where $20 \mathrm{~cm}$ of the surface peat were consumed. The pulse of nutrients leached from the ash, as demonstrated by the analyses of Maclean (1979), moved large quantities of $\mathrm{Fe}$ and $\mathrm{K}$ down the profile to be fixed in unavailable states in clay zones of the lower profile, increasing concentrations in these zones two- to three-fold over the three years succeeding the fire. Elements such as $\mathrm{Ca}, \mathrm{Mg}$ and $\mathrm{P}$ appear to pass right through the profile (Maclean 1979, Bowman \& Jackson 1981, Bowman et al. 1986). 


\section{Nutrient Losses due to Fire in Forest}

Hot wild-fires usually completely kill most, if not all, trees in rainforest and wet sclerophyll forests, so that regeneration is normally wholly dependent on establishment from seed (Gilbert 1959, Barker 1991). Although the potential losses of nutrients in intense wild-fires are high (table 5) relative to the total pools before such fires (for $\mathrm{P}, 76 \%$ in rainforest and $88 \%$ in wet sclerophyll), there are, on the average, long intervals in which the nutrient pools are replenished from inputs from the precipitation and weathering of the geological parent material. In low-intensity fires, the nutrients, especially P, are mobilised in the ash bed. As Adams \& Attiwill (1988, Attiwill et al. 1996) pointed out, the remaining pool of living organisms in the organic upper soil usually prevents serious leaching of the ash bed, although losses through erosion can be serious.

The consequences of losses of elements in high demand by dominant plants (table 3) can cause changes in vegetation structure over generations. Rainforest species have higher demand for $\mathrm{N}$ and $\mathrm{P}$ than eucalypts. Considerable volatile losses of both $\mathrm{N}$ and $\mathrm{P}$ occur in hot fires, and losses of $\mathrm{P}$ by transport of ash are potentially serious (Raison et al. $1985 \mathrm{~b}$ ), since $\mathrm{P}$ is only acquired very slowly from inputs in precipitation and weathering (table 5). The input of $\mathrm{N}$ in precipitation (table 5) supplies some replenishment over time. However, the main source is symbiotic fixation. In eucalypt forests, symbionts in Acacia species and possibly of the Rhamnaceous understorey are variable components. In rainforests, very high levels of $\mathrm{N}$ fixation occur, due to the epiphytic layers of lichens and mosses in the canopy. It is estimated that these fix $\mathrm{N}$ at the rate of about $35-45 \mathrm{~kg} /$ ha/yr in Tasmanian rainforests and mixed forests (Parker 1982: table 7.1, p.139). In wet sclerophyll, the rate of fixation falls to $2-6 \mathrm{~kg} / \mathrm{ha}$, so there is a large drop in $\mathrm{N}$ fixation if a mixed forest is burnt and replaced predominantly by eucalypts.

There has been considerable controversy in the past over the time required for the replacement of nutrients lost from Tasmanian forests due to harvesting by clear felling followed by hot slash-fire to established regeneration (Raison 1981, Neilsen \& Ellis 1981). This problem cannot be resolved until detailed nutrient data are collected. Adams \& Attiwill (1988) proposed that replacement of all nutrients lost from northeastern forests as a result of logging and regeneration fires was conservatively estimated to occur within $80-100$ years from precipitation and weathering. Ellis \& Graley (1983) proposed that replacement could be expected within 15-20 years in the southern forests. The latter estimate appears most unlikely, in view of the probable erosion and leaching losses in this wetter environment. In any case, changes in nutrient supply ratio relative to requirements of the regenerating vegetation is a more important issue.

In dry sclerophyll, the losses relative to pre-fire pools are potentially high, e.g. for $\mathrm{P}$ about $80 \%$ (table 5). Since the intervals free of fire are much shorter, there is a greater drain on nutrient resources. For example, the estimated potential losses of $84 \%$ in the consumable mass of $\mathrm{P}$ in the E. amygdalina dry sclerophyll forest in table 5 must represent a serious cumulative limitation to productivity. This forest was burnt by a fire which defoliated the canopy two years before assessment by Adams \& Attiwill (1988). The main consequence of short-interval recurrent fire regimes is to foster a change from understoreys of woody shrubs to "grassy-sedgy" understoreys. These monocot understoreys have underground energy stores and are capable of rapid vegetative recovery. Their presence further shortens the fire-free interval and creates a serious threat to the growth rates of eucalypt regeneration, as for instance in E. delegatensis forests (Ellis 1986).

In low $\mathrm{P} / \mathrm{E}$ environments, where regeneration is readily obtained without the use of fire, its use even for fuel reduction promotes pyrogenic monocot or bracken understoreys, with associated deterioration in fertility (Boerner 1982). The current management policy of the forest industry of using hot slash-burning to create a highly mineralised ash-bed effect for regeneration in high $\mathrm{P} / \mathrm{E}$ environments also needs to be questioned, especially when applied to low fertility sites. The potential losses of nutrients by erosion and leaching can be serious (tables 5, $6 \& 7$; see also discussion of results of Lockett \& Candy 1984 by Jordan et al. 1992).

\section{Nutrient Losses due to Fire in Non-forest Communities}

As table 5 indicates, the non-forest communities of scrub, heath and sedgeland have lower soil nutrient reserves. The shorter fire-free intervals in non-forest communities places them at far greater risk of nutrient depletion and, with the exception of grassland, the generally lower microbial content of the soils renders them vulnerable to leaching loss. Many of the soils of heaths and most of the sedgeland peats are acid and anaerobic with high water-tables at least in some seasons. As a consequence, the cation-exchange capacity is low. This is not the case with grassland soils, which are well drained and have high cation-exchange capacity.

\section{Heathland}

On the basis of foliar concentrations Australian heath plants have lower nutrient status than other heaths (Specht 1969). The pools of soluble inorganic $\mathrm{N}$ and $\mathrm{P}$ in the soil form a small proportion of the total pools and are in many cases unrelated. Most of the soil analysis in the early literature (pre 1980) measured total pools. A somewhat different picture is found when the available pools are assessed. Adams et al. (1994) showed that, when extractable labile $\mathrm{N}$ and P were determined, the surface organic soils of the heaths on Wilsons Promontory, Victoria, were comparable in availability of $\mathrm{P}$ and $\mathrm{N}$ with soils of most eucalypt forests; also that the concentration of carbon, nitrogen and potentially mineralised nitrogen and phosphatase activity were greater in soils from unburnt heathland than in soils from heath sites repeatedly burnt. In contrast, the concentrations of available $\mathrm{P}$ were greater in soils from repeatedly burnt sites (8-10 yrs) than from unburnt sites $(-40 \mathrm{yrs})$. These effects were limited to the surface $2 \mathrm{~cm}$ of the soil. The sustained increase in available $\mathrm{P}$ and decrease in available $\mathrm{N}$ on frequently burned heathland is attributed to a reduction in the concentration of organic matter. The loss of $\mathrm{N}$ on frequently burnt sites is in excess of total inputs and constitutes a significant reduction in $\mathrm{N}$ stocks.

The findings of Adams et al. (1994) should be applicable to most coastal and near coastal heaths in northern and eastern Tasmania and the islands of Bass Strait. It is likely that similar losses of $\mathrm{N}$ are serious on the wet heaths in montane and western regions. Maclean (1979) argued that the repeated fires on sedgeland/heaths favour the 
development of sedgeland, because of the loss of the divalent cations $\mathrm{Ca}$ and $\mathrm{Mg}$ which are required by heath plants (Maclean 1979, Bowman et al. 1986).

\section{Sedgeland}

All the sedgeland plants have extremely low foliar nutrient concentrations. The common Tasmanian species would appear to have nutrient levels well below most plants treated in the literature. Gymnoschoenus, which dominates the sedgeland heaths over $40 \%$ of western Tasmania (table 1), is remarkable in withdrawing very high amounts (94\%) of $\mathrm{P}$ and $\mathrm{K}$ from the foliage during senescence and then retaining the old foliage on the plant till it slowly decays (table 3). The muck peat formed by the plant is acid, anaerobic and very low in nutrients. Although the peat is high in organic matter, it has very low cation-exchange capacity. The only element to which the plant responds is $\mathrm{K}$ (Maclean 1979). A study of biomass accumulation on different sites by Marsden-Smedley (1998) shows that a steady-state biomass in the southwest on Precambrian parent material of $10 \mathrm{t} / \mathrm{ha}$ is achieved after 30 years, whereas on the dolerite soils on the western edge of the Central Plateau, where $\mathrm{K}$ levels are much higher in the clayey soils, the biomass was $30 \mathrm{t} / \mathrm{ha}$ at 30 years and still increasing. It is almost certain that in the Southwest the loss of approximately $50 \%$ of the total nutrient pool of $\mathrm{K}$. (table 5) in the consumption of the above ground biomass every twenty five years maintains the low production of Gymnoschoenus sedgeland.

\section{CONCLUSIONS}

The overall evidence suggests that in lowland eastern Tasmania, where $\mathrm{P} / \mathrm{E}$ ratios are low, the net losses of nutrients after fire are not as great as might be expected in view of the high average frequency of fire in that environment. There are several reasons for this: (a) the fuel loads are lower so the fires are lower in intensity; (b) the vegetation is highly adapted to recurrent fire, recovering both vegetatively and from fire-promoted release and germination of propagules; (c) in the lower rainfall, the regenerating plants take up the mineralised nutrients in the ash-bed before serious erosion or leaching occurs; and (d) the high clay content of dolerite soils binds leached nutrients in unavailable forms which can, over time, become available to the vegetation. In contrast, in western and southern environments of high $\mathrm{P} / \mathrm{E}$ ratios the vegetation consists of forests poorly adapted to fire and of sedgeland/heaths well adapted to recurrent fire. The palaeovegetation evidence (Jackson 1999d) shows that the sedgeland/heath is a response to the higher frequency of fire resulting from human presence since the Late Pleistocene. The data on differences in input-output concentration nutrients in western watersheds indicate that, in the present interglacial climate, the nutrients in vegetation mineralised by fire are liable to be lost to the run-off water, because in the high rainfall-low evaporation climate the soils are saturated most of the time. There are few clay minerals in most soils in the west to prevent loss by leaching or to capture the relatively large inputs in the precipitation. The vegetation is awash with water and nutrients which it cannot retain. Thus, the nutrients in mineralised ash will largely be lost. The effect of gravitational loss of soil nutrients is a pervading feature of western landscapes (fig. 1). In the present fire regimes, the sedgeland community has little, if any, chance of succession towards forest, and the forest communities are at constant risk of sedgeland advance.

Since the incidence of natural lightning-induced fire in Tasmania is extremely low (Jackson \& Bowman 1982, Ingles 1985), the problems of fire incidence are human ones. With the vastly improved access to remote areas, these problems can only increase. Most of Tasmania has been burnt by extensive landscape scale wild-fire once or twice in each of the last two centuries (Marsden-Smedley 1998). Because such fires occur in extreme fire-danger conditions during periods of drought when fuels are exceptionally dry, the fires are intense and extensive. Estimates of nutrient loss in such intense fires are made in table 5 . These losses added to the losses of nutrients incurred in each rotation of forest crop outweigh the likely rate of nutrient retention from precipitation and weathering. Hence, there is an economic need to conserve nutrients by reducing the incidence of wild-fire and by reducing the losses due to the deliberate use of fire. This need is over and above the need to protect our visual wilderness and the direct loss of assets in forests (Jackson \& Brown 1999). The widespread use of fuel-reduction burning is clearly not the answer, since this only causes further losses of nutrients and fosters changes in the vegetation towards finer fuels with vegetative reproduction. As Boerner (1982) has emphasised, the replacement of the normal shrub storeys with such pyrogenic plants leads to increasing frequency of fire and consequent decrease in soil fertility. One measure which might be taken to reduce the extent of wild-fire in Tasmania would be to maintain bands of low fuel loads in sedgeland adjoining forests by regular patch-burning following Aboriginal traditions in conditions where the fire will not enter the scrub boundary (Nicholson 1981, Marsden-Smedley 1998).

Slash-burning of cut-over forests in regions of high $\mathrm{P} / \mathrm{E}$ ratios should not be used to regenerate forest crops, in view of the potential losses by erosion and leaching inferred by the data on differences in input-output concentration of elements (table 6) in these wet environments. The need for hot slash-fire in high $\mathrm{P} / \mathrm{E}$ ratio environments should be reassessed in view of the potential nutrient losses. Leaving slash to decay naturally in these wet environments does not present a fire hazard and would conserve nutrients and the understorey diversity without the risk of accidental escape of fire.

There is an obvious paucity of data on which to base an important resource industry for Tasmania. The effects of forest practices on soil fertility, plant diversity and pyrogenic developments in understorey composition need to be systematically assessed.

\section{REFERENCES}

Adams, M.A. \& Attiwill, P.M., 1988: Nutrient cycling in forests of north-east Tasmania. Tasm. For. Res. Counc. Res. Rep. 1.

Adams, M.A., Iser, J., Keleher, A.D. \& ChEAl, D.C., 1994: Nitrogen and phosphorus availability and the role of fire in heathlands. Aust. J. Bot. 42: 269-281.

Ashton, D.H., 1975: Studies on litter of Eucalyptus regnans F. Muell. forests. Aust. I. Bot. 23: 413-433.

AtTiwill, P.M., 1980: Nutrient cycling in a Eucalyptus obliqua (L'Herit) forest IV. Nutrient uptake and nutrient return. Aust. J. Bot. 28: 199-222. 
AtTiwill, P.M. \& Leeper, G.W., 1987: FOREST SOILS AND NUTRIENT CYCLES. Melbourne University Press, Melbourne: $202 \mathrm{pp}$.

Attiwill, P.M., Polglase, P.J., Weston, C.J. \& Adams, M.A., 1996: Nutrient cycling in forests of south-eastern Australia. In Attiwill, P.M. \& Adams, M.A. (Eds): NUTRITION OF EUCALYPTS. CSIRO, Melbourne: 191-227.

Ayers, G.P. \& IVeY, J.P., 1988: Precipitation composition at Cape Grim 1977-1985. Tellus 40B: 297-307.

Baker, T.G. \& AtTrWill, P.M., 1985: Above-ground nutrient distribution in Pinus radiata (Don.) and Eucalyptus obliqua (L'Héric) forests in south-eastern Australia. For. Ecol. Manage. 13: 41-52.

BARKER, M., 1991: The effect of fire on west coast lowland rainforest. Tasm. Rainfor. Conserv. Prog. Tech. Rep. 7. Forestry Commission of Tasmania: Hobart

Botrner, R.E.J., 1982: Fire and nutrient cycling in temperate ecosystems. Bioscience 32: 187-192.

BOWMAN, D.M.J.S. \& JACKSON, W.D., 1981: Vegetation succession in south-west Tasmania. Search 12: 358-362.

Bowman, D.M.J.S., Maclean, A.R. \& Crowden, R.K., 1986: Vegetation - soil relations in the lowlands of south-west Tasmania. Aust. J. Ecol. 11: 141-153.

BRESNEHAN, S.J., 1998: AN ASSESSMENT OF FUEL CHARACTERISTICS AND FUEL LOADS IN DRY SCLEROPHYLL FORESTS IN SOUTH-EAST TASMANIA. Report to the Tasmanian Forest Research Council. Hobart, Tasmania: 90 pp.

Brown, M.J., 1999: Buttongrass moorlands, In Reid, J.B., Hill, R.S., Brown, M.J. \& Hovenden, M.J. (Eds): VEGETATION OF TASMANIA. Aust. Biol. Resour. Stud. (Ser.: FLORA OF AUSTRALIA, Suppl. ser. 8). Canberra. Ch. 13: 286-303.

Buckney, R. \& Tyler, P.A., 1973: Chemistry of Tasmanian inland waters. Int. rev, gesamten Hydrobiol. 58: 61-78.

Cheney, N.P.,1981: Fire behaviour. In Gill, A.B., Groves, R.H. \& Noble, I.R. (Eds): FIRE AND THE AUSTRLIAN BIOTA. Australian Academy of Science, Canberra: 151176

Colmoun, E.A., 1985: Glaciations of the West Coast Range, Tasmania. Quat. Res. 24: 39-58.

Colhoun, E.A., 1986: Field problems of radiocarbon dating in Tasmania. Pap. Proc. R. Soc. Tasm. 120: 1-6.

Colhoun, E.A. \& van De Geer, G., 1998: Pollen analysis of 0$20 \mathrm{~m}$ at Darwin Crater, western Tasmania, Australia. In Horie, S. (Ed.): INTERNATIONAL PROJECT ON PALAEOLIMNOLOGY AND LATE CAINOZOIC CLIMATE. IPPCE 11: 68-89.

Cosgrove, R., 1995: Late Pleistocene behavioural variation and time trends: the case from Tasmania. Archeol. Oceania 30: 83-104.

DUNCAN, F., 1990: Eucalypts in Tasmania's changing landscape. Tasm. For. 1: 13-25.

ELLIS, R.C., 1986: The relationship between sub-alpine grassland and forest communities in northern Tasmania. In Barlow, B.A. (Ed.): FLORA AND FAUNA OF ALPINE AUSTRALIA AGES AND ORIGINS. CSIRO, Melbourne: 243-245.

Ellis, R.C. \& Graley, A.M., 1983: Gains and losses in soil nutrients associated with harvesting and burning eucalypt rainforest. Plant Soil 74: 437-450.

Ellis, R.C. \& GRaleY, A.M., 1987: Soil chemical properties as related to forest succession in a highland area in northeast Tasmania. Aust. J. Ecol. 12: 307-317.

Felier, M.C., 1981: Catchment nutrient budgets and geological weathering in Eucalyptus regnans ecosystems in Victoria. Aust. J. Ecol. 6: 65-77.

FEnSHAM, R.J., 1989: The pre-European vegetation of the Midlands Tasmania floristic and historical analysis of vegetation pattern. J. Biogeogr. 16: 29-45.
Fisher, R.F. \& BinkLeY, D., 2000: Fire effects. In Fisher, R.F. \& Binkley, D. (Eds): ECOLOGY AND MANAGEMENT OF FOREST SOILS. J. Wiley \& Sons, New York: Ch. 10: $1-15$.

Fitzsimons, S.J. \& Colhoun, E.A., 1991: Pleistocene glaciation of the King Valley, Western Tasmania, Australia. Quat. Res. 36: 135-156.

FuinN, D.W., Bren, L.J. \& Hopmans, P., 1979: Soluable nutrient inputs from rain and outputs in stream water from small forested catchments. Aust. For. 42: 39-49.

Frankombe, D.W., 1966: The regeneration burn. Appita 19: $127-132$

Gilbert, J.M., 1959: Forest succession in the Florentine Valley Tasmania. Pap. Proc. R. Soc. Tasm. 93: 129-151.

Guthrie, H.B., Attrwill, P.M. \& Lleuning, R., 1978: Nutrient cycling in a Eucalyptus obliqua (L'Herit) forest II. A study in a small catchment. Aust. J. Bot. 26: 189-201.

HARWoOD, C.E., 1972: Nutrient studies in south-west Tasmanian vegetation. Unpubl. BSc Honours thesis, Dep. Botany, Univ. Tasm., Hobart.

HarwoOD, C.E. \& JACKSON, W.D., 1975: Atmospheric losses of four plant nutrients during a forest fire. Aust. J. For. 38: 92-99.

HILl, R.S. \& ReAD, J., 1984: Post-fire regeneration of rainforest and mixed forest in western Tasmania. Aust. J. Bot. 32: 481-493.

Holland, P.G. \& STEYN, D.G., 1975: Vegetation responses to latitudinal variations in slope angle and aspect. J. Biogeogr. 2: $179-183$

INGLES, A., 1985: FIRE. Environmental impact statement into the continuation of woodchip exports from Tasmania after 1990. Working paper 5. Gov. Printer, Hobart.

JACKSON, W.D., 1965: Vegetation. In Davies, J.R. (Ed.): ATLAS OF TASMANIA. Lands and Surveys, Hobart: 30-35.

JACKSON, W.D., 1968: Fire, air, water and earth - an elemental ecology of Tasmania. Proc. Ecol. Soc. Aust. 3: 9-16.

JACKSON, W.D., 1973: Vegetation of the Central Plateau. In Banks, M.R. (Ed.): THE LAKE COUNTRY. Royal Society of Tasmania, Hobart: 61-86.

JACKSON, W.D., 1977: Nutrient cycling in Tasmanian oligotrophic environments. In PROC. SYMP. NUTRIENT CYCLING AND INDIGENOUS FOREST ECOSYSTEMS. CSIRO, Div. of Land Resource Management, Perth, WA:122123.

JACKSON, W.D., 1981: Vegetation and fire patterned vegetation. In Jackson, W.D. (Ed.): VEGETATION OF TASMANIA. XIII International Botanical Congress, Sydney Field Trip 28. Australian Acadademy of Science, Canberra:1-35.

JACKSON, W.D., 1999a: Vegetation types. In Reid, J.B., Hill, R.S., Brown, M.J. \& Hovenden, M.J. (Eds): VEGETATION OF TASMANIA. Aust. Biol. Resour. Stud. (Ser.: FLORA OF AUSTRALIA, Suppl, ser. 8). Canberra. Ch. 1: 1-10.

JACKSON, W.D., 1999b: The Tasmanian environment. In Reid, J.B., Hill, R.S., Brown, M.J. \& Hovenden, M.J. (Eds): VEGETATION OF TASMANIA. Aust. Biol. Resour. Stud. (Ser.: FLORA OF AUSTRALIA, Suppl. ser. 8). Canberra. Ch. 2: 1-38.

JACKSON, W.D., 1999c: Palaeohistory of vegetation change - the last 2 million years. In Reid, J.B, Hill, R.S, Brown, M.J \& Hovenden, M.J (Eds.): VEGETATION OF TASMANIA. Aust. Biol. Resour. Stud. (Ser.: FLORA OF AUSTRALIA, Suppl. ser. 8). Canberra. Ch. 4: 64-88.

JACKSON, W.D., 1999d: The Tasmanian legacy of man and fire. Pap. Proc. R. Soc. Tasm. 133: 1-14.

JACKSON, W.D. \& BOWMAN, D.M.J.S., 1982: Slash burning in Tasmanian dry eucalypt forests. Comment. Aust. For. 1: 63-67.

JACKSON, W.D. \& BroWN, M.J., 1999: Pattern and process in vegetation. In Reid, J.B., Hill, R.S., Brown, M.J. \& Hovenden, M.J. (Eds): VEGETATION OF TASMANIA. 
Aust. Biol. Resour. Stud. (Ser.: FLORA OF AUSTRALIA, Suppl. ser. 8). Canberra. Ch.16: 357-380.

JACOBS, M.R., 1955: GROWTH HABITS OF THE EUCALYPTS. Commonwealth Gov. Printer, Canberra.

Jordan, G.J., Patmore, C., Duncan, F. \& Luttrell, S., 1992: The effects of fire intensity on the regeneration of mixed forest species in the Clear Hill Mt Wedge area. Tasforests 4: 25-38.

Khanna, P.K. \& Raison, R.J., 1986: Effects of fire intensity on solution chemistry of surface soil Aus. J. Soil Res. 24: $423-434$

Kiernan, K., 1989: Muliple glaciation of the upper Franklin Valley, Western Tasmania Wilderness World Heritage Area. Aust. Geogr. Stud. 27: 208-235.

Kiernan, K., 1990: The extent of Late Cenozoic glaciation in the Central Highlands of Tasmania, Australia. Arct. Alp. Res. 22: 341-354

Kiernan, K. \& Hannan, D., 1991: Glaciation of the upper Forth River catchment Tasmania. Aust. Geogr. Stud. 29: 155-173.

KIRKPATRICK, J.B. \& DICKINSON, K.J.M., 1984a: VEGETATION MAP OF TASMANIA 1:500,000. Forestry Commission, Hobart.

Kirkpatrick, J.B. \& Dickinson, K.J.M., 1984b: The impact of fire on Tasmanian alpine vegetation and soils. Aust. J. Bot. 32: 613-629.

KirkPATRICK, J.B. \& HaRrIS, S., 1999: Coastal heath and wetland vegetation. In Reid, J.B., Hill, R.S., Brown, M.J. \& Hovenden, M.J. (Eds): VEGETATION OF TASMANIA. Aust. Biol. Resour. Stud. (Ser.: FLORA OF AUSTRALIA, Suppl, ser. 8). Canberra. Ch. 14: 304-332.

Kirkpatrick, J.B., Barker, P., Brown, M.J., Harris, S. \& Mackie, R., 1995: The reservation status of Tasmanian vascular plant communities. Wildl. Sci. Rep. 95/4. Parks \& Wildlife Service of Tasmania, Hobart.

LING RotH, H., 1899: THE ABORIGINES OF TASMANIA 2nd edn. King \& Sons, Halifax England.

LLOYD, P.S., 1971: Effects of fire on the chemical status of herbaceous communities of the Derbyshire Dales. J. Ecol. 59: 261-273

LocketT, E. \& Candy, S.G., 1984: Growth of eucalypt regeneration established with and without slash burns in Tasmania. Aust. For. 47: 119-125.

McArThur, A.G., 1968: The Tasmanian bushfires of 7 th February 1967, and associated fire behaviour characteristics. In CONFERENCE PAPERS, 2ND AUSTRALIAN NATIONAL CONFERENCE ON FIRE, SYDNEY AUSTRALIA. Fire Protection Association, Melbourne: $25-48$.

MaClean, A.R., 1979: Mineral nutrients in soil and vegetation of sedgeland and heathland communities in south-west Tasmania. Unpubl. BSc Hons thesis, Dep. Botany, Univ. Tasm., Hobart.

Marsden-Smedley, J.B., 1998: Changes in southwest Tasmania fire regimes since the early 1800s. Pap. Proc. $R$. Soc Tasm. 132: 15-29.

MitCHELl, A., 1962: REPORT ON SOIL CONSERVATION PROBLEMS ON THE CENTRAL PLATEAU AND SOUTH ESK RIVER CATCHMENT IN TASMANLA. Report submitted to the Standing Committee on Conservation of Natural Resources of Tasmania.

NeILSEN, W.A. \& ELlis, R.A., 1981: Slash burning on forest sites: further comments. Search 12: 9-10.

Nicholson, P.H., 1981: Fire and the Australian Aborigines - an enigma. In Gill, A.M., Groves, R.H. \& Noble, I.R. (Eds): FIRE AND THE AUSTRALIAN BIOTA. Australian Academy of Science, Canberra 3: 56-76.

Noble, I.R. \& Slatyer, R.O., 1981: Concepts and models of succession in vascular plant communities subject to recurrent fire. In Gill, A.M., Groves, R.H. \& Noble, I.R
(Eds): FIRE AND AUSTRALIAN BIOTA. Australian Academy of Science, Canberra: 311-335.

NunEz, M., 1978: The radiation index of dryness in Tasmania. Aust. Geogr. Stud. 16: 126-135.

OLSEN, J.H., 1963: Energy storage and the balance of producers and decomposers in ecological systems. Ecology 44: 322 331.

PARKER, S.E., 1982: Nitrogen fixing non-leguminous symbiosis. Unpubl. BSc Hons thesis, Dep. Plant Science, Univ. Tasm., Hobart.

Polgi.ase, P.J., Attrwell, P.M. \& Adams, M.A., 1986: Immobilization of soil nitrogen following wildfire in two eucalypt forests of south-eastern Australia. Oecol. Plant. 7: 261-272

PRYOR, L.D. 1976: THE BIOLOGY OF EUCALYPTS. Edward Arnold, London.

RaIsON, R.J., 1981: More on the effects of intense fires on the long-term productivity of forest sites: reply to comments. Search 12: 10-14.

Raison, J.R., Woods, P.V. \& Khanna, P.K., 1983: Dynamics of fine fuels in recurrently burnt eucalypt forests. Aust. For. 46: $294-302$

Raison, R.J., Khanna, P.K. \& Woods, P.V., 1985a: Mechanisms of element transfer to the atmosphere during vegetation fires. Can. J. For. Res. 15: 132-140

Raison, R.J., Khanna, P.K. \& WoOds, P.V., 1985b: Transfer of elements to the atmosphere during low-intensity prescribed fires in three Australian subalpine eucalypt forests. Can. J. For. Res. 15: 657-664.

Raison, R.J., KiEt'H, H. \& Khanna, P.K., 1990: Effects of fire on the nutrient supplying capacity of forest soils. In Dyck, W.J. \& Mees, C.A. (Eds): IMPACT OF INTENSIVE HARVESTING ON FOREST SITE PRODUCTIVITY. FRI (Rotorua, N.Z.) Bull. 159: 39-54.

Raison, R.J., O'Conneli, A.M., Khanna, P.K. \& Keith, H., 1993: Effects of repeated fires on nitrogen and phosphorus budgets and cycling processes in forest ecosystems. In Trabaud, L. \& Prodon, R. (Eds): FIRE IN MEDITERRANEAN ECOSYSTEMS. ECSC-EEC-EAEC Brussels 5: 347-363.

Reid, J.B. \& Potts, B.M., 1999: Eucalypt biology. In Reid, J.B., Hill, R.S., Brown, M.J. \& Hovenden, M.J. (Eds): VEGETATION OF TASMANIA. Aust. Biol. Resour. Stud. (Ser.: FLORA OF AUSTRALIA, Suppl. ser. 8). Canberra. Ch. 9: 198-223.

Reid, J.B., Hill, R.S., Brown, M.J. \& Hoveden, M.J. (Eds), 1999. VEGETATION OF TASMANIA. Aust. Biol. Resour. Stud. (Ser.: FLORA OF AUSTRALIA, Suppl. ser. 8). Canberra: $441 \mathrm{pp}$.

ScotT, P., 1956: Variability of annual rainfall in Tasmania. Pap. Proc. R. Soc. Tasm. 90: 49-57.

Seymour, D.B. \& Calver, C.R., 1995: STRATOTECTONIC ELEMENTS MAP 1:5000 000 series. Tasmania Development and Resources and Australian Geological Survey Organization, Hobart.

SPECHT, R.L., 1969: A comparison of the sclerophyllous vegetation characteristic of Mediterranean-type climate in France, California and southern Australia. Dry matter, energy and nutrient accumulation. Aust. J. Bot. 17: 293-308.

Turnbull, C.R.A. \& MadDen, J.L., 1983: Relationship of litterfall to basal area and climatic variables in cool temperate forests of Southern Tasmania. Aust. J. Ecol. 8: 425-431

Vitouser, P.M. \& Matson, P.A., 1984: Mechanisms of nitrogen retention in forest ecosystems: a field experiment. Science 225: $51-52$

Walker, J., Raison, R.J. \& KhanNa, P.K., 1986: Fire. In Russell, J.S. \& Isbell, R.F. (Eds): THE IMPACT OF HUMAN ACTIVITIES ON AUSTRALIAN SOILS. University of Queensland Press, Brisbane: 185-216. 
Wells, P. \& Hickey, J., 1999: Wet sclerophyll, mixed and swamp forest. In Reid, J.B., Hill, R.S., Brown, M.J. \& Hovenden, M.J. (Eds): VEGETATION OF TASMANIA. Aust. Biol. Resour. Stud. (Ser.: FLORA OF AUSTRALIA, Suppl. ser. 8). Canberra. Ch. 10: 224-243.

(accepted 17 May 2000) 